\title{
Evolution of the Palaeozoic basement of the North Patagonian Andes in the San Martín de los Andes area (Neuquén, Argentina): petrology, age and correlations
}

\author{
Samanta Serra-Varela ${ }^{1}$, Pablo D. González ${ }^{1}$, Raúl E. Giacosa ${ }^{2}$, Nemesio Heredia ${ }^{3}$, \\ David Pedreira $^{4}$, Fidel Martín-González ${ }^{5}$, Ana María Sato ${ }^{6}$
}

\author{
${ }^{1}$ Instituto de Investigación en Paleobiología y Geología, Universidad Nacional de Río Negro, Avda. Roca 1242, 8332 Argentina. \\ ssvarela@unrn.edu.ar;pdgonzalez@unrn.edu.ar \\ 2 Servicio Geológico Minero Argentino (SEGEMAR), Delegación Comahue, Independencia 1495, General Roca, Río Negro, Argentina. \\ giacosaraul@yahoo.com.ar \\ 3 Instituto Geológico y Minero de España, c/Matemático Pedrayes 25, 33005 Oviedo, España. \\ n.heredia@igme.es \\ ${ }^{4}$ Departamento de Geología, Universidad de Oviedo, c/Jesús Arias de Velasco s/n, 33005 Oviedo, España. \\ david@geol.uniovi.es \\ ${ }_{5}$ Área de Geología ESCET Universidad Rey Juan Carlos, c/Tulipán s/n, 28933 Móstoles, Madrid, España. \\ fidel.martin@urjc.es \\ ${ }^{6}$ Centro de Investigaciones Geológicas (UNLP-CONICET), Diagonal 113 N²75, La Plata, Buenos Aires, Argentina. \\ sato@cig.museo.unlp.edu.ar
}

\begin{abstract}
In San Martín de los Andes area (Argentinian Patagonia) the Palaeozoic basement consists of metamorphic and plutonic rocks. The metamorphic rocks include strongly deformed schists, gneisses and migmatites. Their geochemical and petrographic characteristics suggest that the protholith could have been a sequence of pelites and greywackes. Detrital zircon analysis (U-Pb Q-ICP-LA-MS) yielded a maximum depositional age of 501 $\pm 14 \mathrm{Ma}$ (Series 3 Cambrian) for this sedimentary protolith. Metasedimentary rocks are affected by a regional foliation defined by the minerals of the metamorphic peak. This is a S2 foliation, since relics of a former foliation are present in some samples. This regional foliation is locally affected by open folds that develop an incipient crenulation cleavage (S3). The high-grade metamorphism includes partial melting processes, where the incipient segregates intrude parallel to the regional foliation and also cut it in presence of abundant melt. Zircons from anatectic granites formed during this partial melting process yielded a U-Pb Concordia age of 434.1 \pm 4.5 Ma (Llandovery-Wenlock, Silurian). The age of maximum sedimentation and the anatectic age constrain the metamorphic evolution of the basement into the lower Palaeozoic (between upper Cambrian and lower Silurian). The igneous rocks of the basement are granodiorites, tonalities, and some gabbros that cut the metamorphic basement and contain xenoliths and roof pendants from the country rocks. These plutonic rocks are affected by low-grade metamorphism, with the development of discrete, centimetric to hectometric, brittle-ductile shear zones. The age of these igneous rocks has been constrained through U-Pb zircons analysis, carried out by several authors between $c a$. 370 and $400 \mathrm{Ma}$ (Devonian). The maximum sedimentation age for the protolith and its metamorphic evolution seems to be related to an early Palaeozoic orogenic event, probably the Patagonian Famatinian orogeny. In contrast, the Devonian igneous rocks of San Martín de los Andes could represent a Devonian magmatic arc, related to subduction processes developed at the beginning of the Gondwanan orogenic cycle, which culminates with the Gondwanan orogeny.
\end{abstract}


RESUMEN. Evolución del basamento paleozoico de los Andes Norpatagónicos en el área de San Martín de los Andes (Neuquén, Argentina): petrología, edad y correlaciones. En el entorno de San Martín de los Andes (Patagonia argentina), el basamento Paleozoico está constituido por rocas metamórficas e ígneas. Las rocas metamórficas de esta área incluyen esquistos, gneises y migmatitas intensamente deformadas. Según sus características geoquímicas y petrográficas, el protolito de las mismas es considerado una alternancia de pelitas y grauvacas. Análisis de circones detríticos (U-Pb

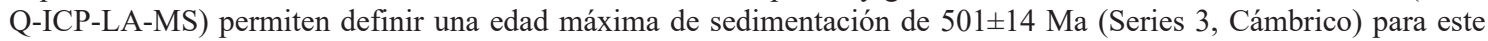
protolito sedimentario. Las rocas metasedimentarias se encuentran afectadas por una foliación regional definida por la asociación principal del pico metamórfico. Esta es una foliación de tipo S2, ya que se encuentran relictos de una foliación anterior en algunas muestras. Esta foliación regional, está localmente afectada por pliegues abiertos donde se desarrolla un clivaje de crenulación incipiente (S3). El metamorfismo de alto grado incluye un evento de fusión parcial, donde los primeros segregados se introducen a favor de la foliación S2 y la cortan en presencia de abundante fundido. Circones obtenidos de un granito anatéctico producido durante este evento de fusión parcial arrojaron una edad Concordia U-Pb de 434.1 \pm 4.5 Ma (Llandovery-Wenlock, Silúrico). La edad máxima de sedimentación y la edad de anatexis permiten acotar la evolución de las rocas metamórficas del basamento al Paleozoico inferior (entre el Cámbrico tardío y el Silúrico temprano). Las rocas ígneas del basamento son granodioritas y tonalitas, con menor proporción de gabros, las cuales cortan las rocas metamórficas y contienen xenolitos y roof pendants de las mismas. Por otra parte, estas rocas plutónicas fueron afectadas por un metamorfismo de bajo grado que llevan asociadas zonas de cizalla frágil-dúctil centimétricas a hectométricas. Edades U-Pb SHRIMP en circones restringe la edad de estas rocas entre 370 y 400 Ma (Devónico). La edad máxima de sedimentación de los protolitos de las rocas metamórficas y su evolución metamórfica podría estar relacionada a un evento orogénico del Paleozoico temprano, probablemente a la orogenia Famatiniana Patagónica. En contraste, las rocas plutónicas de San Martín de los Andes representarían un arco magmático, relacionado a una subducción que se habría producido al comienzo del ciclo orogénico Gondwánico, el cual culmina con la orogenia Gondwánica.

Palabras clave: Basamento paleozoico, Andes norpatagónicos, Poliorogénico, Orogenia famatiniana, Orogenia gondwánica.

\section{Introduction}

The igneous and metamorphic basement of the North Patagonian Andes presents itself as scattered outcrops between the surroundings of the localities of Aluminé, San Martín de los Andes, Bariloche, El Bolsón, El Maitén and Esquel (Cingolani et al., 2011; Varela et al., 2005 and references therein). These rocks have been interpreted as part of a Palaeozoic basement, but both the relationships between them and their correspondence with an orogenic cycle are still unclear

In Bariloche region, García-Sansegundo et al. (2009) describe a metamorphic basement deformed by the Gondwanan orogeny during late Carboniferous-early Permian time. Later, Martínez et al. (2012) proposed a Middle Devonian-early Carboniferous age for this metamorphism, which they correlate with the Chanic orogenic event. In the Aluminé area the metamorphism was associated to a Carboniferous orogenic event (Urraza et al., 2011). In contrast, metamorphic rocks from San Martín de los Andes have been related to at least two orogenic events, one in the early Palaeozoic (pre-Devonian) and another one in the late Palaeozoic, probably related to the Gondwanan orogenic cycle (Serra-Varela et al., 2016). Recently, Heredia et al. $(2016,2018)$ considered a pre-Wenlock age for the early Palaeozoic orogenic event, suggesting the name of Patagonian Famatinian orogeny. These authors also proposed a two-stage development for the Gondwanan orogeny. The older stage was related to subduction and was Middle Devonian-Early Carboniferous in age. This stage corresponds to the Chanic orogenic event of Martínez et al. (2012), event that Heredia et al. (2016) consider restricted to the Cuyo Sector, located farther to the N. Later, a collisional stage of late Carboniferous-early Permian age closes the Gondwanan orogenic cycle.

The aim of this study is to provide new petrological, structural, geochemical and geochronological data for the characterization and correlation of the preMesozoic basement outcrops of the North Patagonian Andes, with special emphasis in the study of an early Palaeozoic tectono-metamorphic event that affects this basement in the surroundings of San Martín de los Andes. This new data help placing the North Patagonian basement in the context of the Palaeozoic orogenic cycles recently proposed by Heredia et al. (2016).

\section{Geological setting}

The study area is located in Neuquén Province (Argentina), between the Lácar and Curruhué lakes, in 
the surroundings of the San Martín de los Andes locality (Fig. 1). The studied rocks belong to the Patagonian Sector of the Argentinean-Chilean Andes basement (Heredia et al., 2016, 2018), mainly constituted by metamorphic and igneous rocks (Fig. 1b).

Initially, the basement rocks from the North Patagonian Andes were included in the Colohuincul Complex (Dalla Salda et al., 1991; Turner, 1965). These authors described a complex formed by highgrade metamorphic rocks and two igneous units, called San Martín de los Andes Tonalite and Lago Lácar Granodiorite. The high-grade metamorphic rocks comprise mainly migmatites and gneisses with minor schists (Fig. 2).

The age of these high-grade metamorphic rocks has been matter of discussion in recent years. A Neoproterozoic age was proposed by Dalla Salda et al. (1991), based on Rb-Sr ages of ca. $860 \mathrm{Ma}$. However, more recent studies constrained the maximum deposition age of the protolith in this area

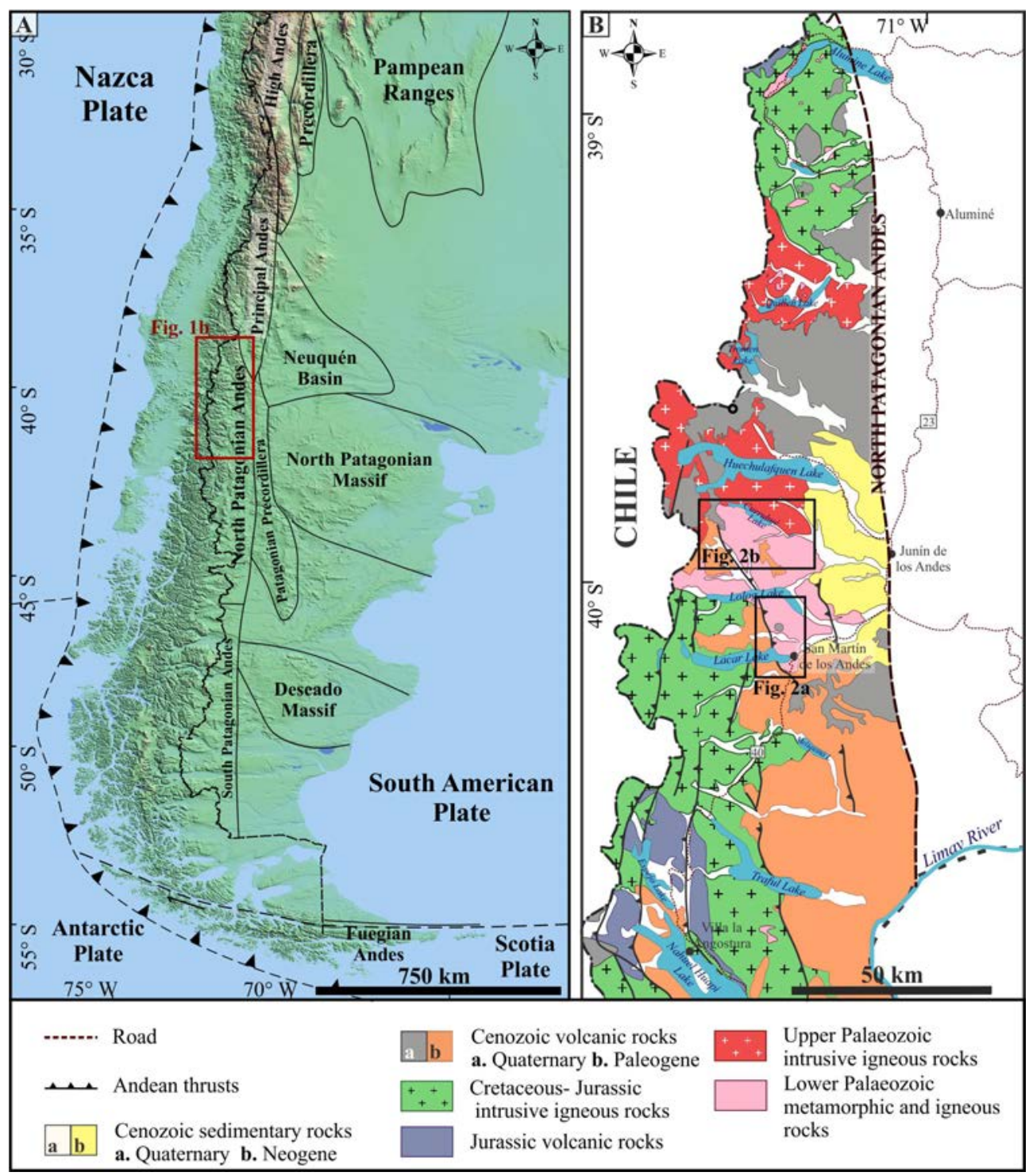

FIG. 1. A. Geographic location of the studied area modified from Ramos (1975); B. Geological context of the studied area with the location of the geological maps of figures 2A and 2B. Modified from Leanza et al. (2011). 


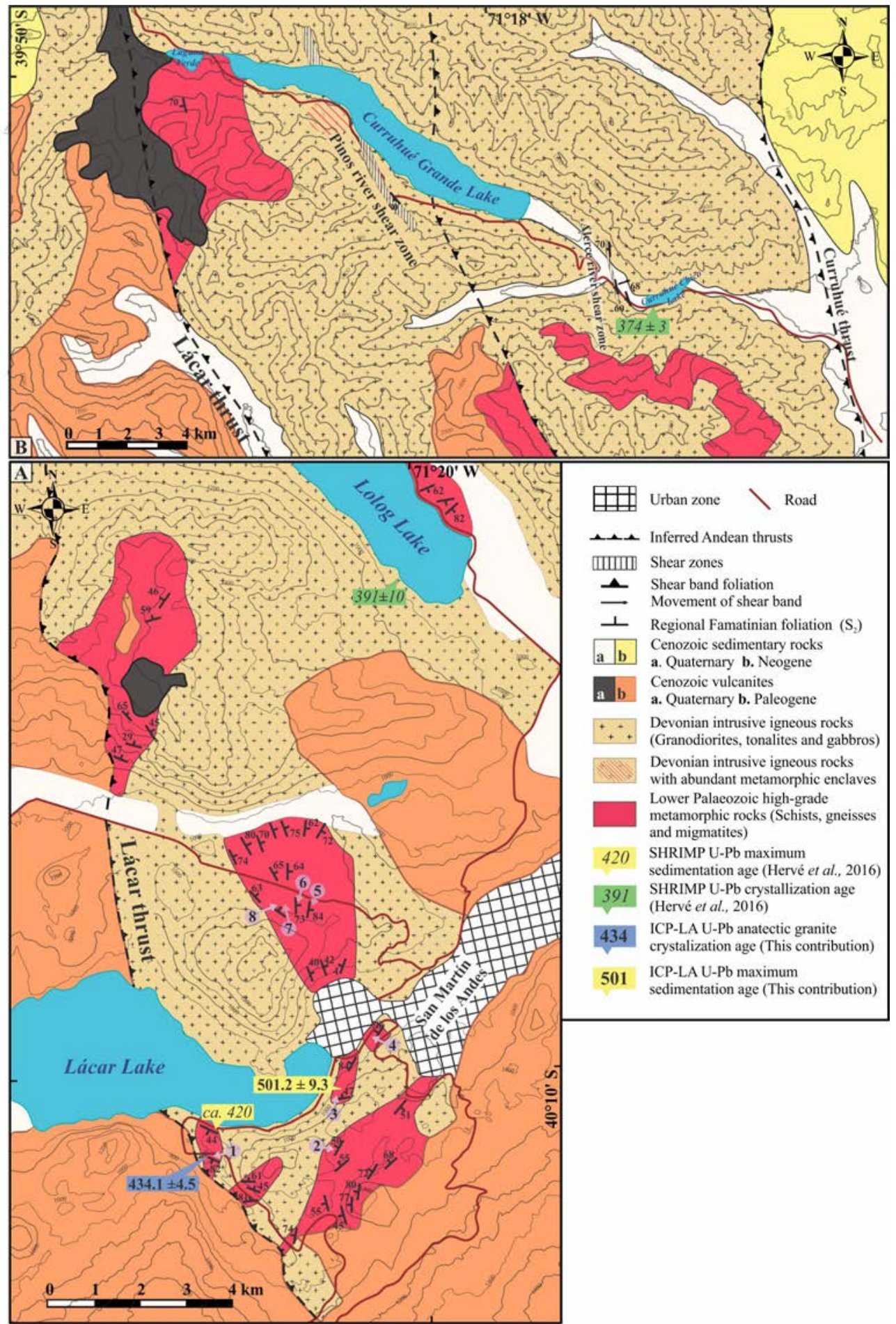

FIG. 2. A. Geological sketch map of the area located between the Lácar and Lolog lakes, showing the distribution of the main lithological units. The small purple circles indicate the location of the analyzed samples of table 1: 1) SMA74; 2) SMA96; 3) SMA98; 4) SMA84; 5) SMA86; 6) SMA86a; 7) SMA89; 8) SMA89a. B. Geological sketch map of the Curruhué Grande lake area. Modified from Cucchi and Leanza (2006). See location in figure 1B. 
in ca. 420 Ma (Hervé et al., 2016). Additionally, Serra-Varela et al. (2016) proposed for the same protolith a maximum sedimentation age of ca. $506 \mathrm{Ma}$ based on U-Pb Q-ICP-MS-LA detrital zircons analysis. This discrepancy between this age data will be discussed later in this contribution. Crystallization ages for the San Martín de los Andes Tonalite and the Lago Lácar Granodiorite have been constrained by $\mathrm{U}-\mathrm{Pb}$ zircon analysis at $c a .400 \mathrm{Ma}$ (Hervé et al., 2016, 2013; Pankhurst et al., 2006; Varela et al., 2005).

The high-grade metamorphic rocks crop out as roof pendants or xenoliths within the Devonian plutonic units and the contact between them is locally sharp, indicating a pre-Devonian age for these metamorphic rocks (Serra-Varela et al., 2015, 2016) (Fig. 2A and B). Both high-grade metamorphic and igneous rocks are covered by Paleogene volcanic and volcaniclastic rocks from the Huitrera Formation (Escosteguy and Franchi, 2010; Ravazolli and Sesana, 1977).

The geological evolution of the basement rocks in San Martín de los Andes was initially considered as the result of a single tectonic cycle that included both the igneous and metamorphic rocks (Dalla Salda et al., 1991). Recently, Serra-Varela et al. (2016) proposed a separate tectonic evolution for the high-grade metamorphic rocks and Devonian granitoids, based on their different deformational styles and field relationships. According to these authors the San Martín de los Andes Tonalite and Lago Lácar Granodiorite, which cut the high-grade metamorphic rocks, are considered post-tectonic intrusions of a pre-Devonian tectono-metamorphic event, although they are also deformed by a later orogenic event. Thus, the Devonian igneous rocks are deformed by a single orogenic cycle (in late Palaeozoic times) while the high-grade metamorphic rocks are affected by at least two different orogenic cycles (in early and late Palaeozoic times).

\section{Petrographic characteristics of the main basement rocks}

The most common metamorphic rocks are gneisses and schists in close association with metatexites and diatexites (in the sense of Sawyer, 2008). These types of rocks show transitional contacts between them. The Devonian igneous rocks comprise large volumes of granodiorites and tonalites. Minor gabbroic rocks are found in the area and have a transitional contact with granodiorites, suggesting that they are genetically and temporarily related.

\subsection{Metasedimentary rocks}

The metasedimentary rocks are predominantly gneisses with minor schists (Fig. 3A). We distinguish one main metamorphic assemblage in schists (Fig. 3B): Qtz $+\mathrm{Pl}+\mathrm{Bt}+\mathrm{Crd}+\mathrm{Sil}$ (fibrolite) $\pm \mathrm{Ms} \pm \mathrm{Kfs} \pm \mathrm{Gr}$ (Mineral abreviations according to Siivola and Schmid, 2007) and one main metamorphic assemblage in gneisses: $\mathrm{Qtz}+\mathrm{Pl}+\mathrm{Bt}+\mathrm{Ms}+\mathrm{Crd} \pm \mathrm{Sil}$ (fibrolite) \pm Kfs.

Commonly the metasedimentary sequences include alternate layers of schists and gneisses, most likely reflecting the original sedimentary bedding. Chlorite, epidote, sericite and prehnite are the common low-temperature association replacing the main assemblages.

\subsection{Metatexite migmatites}

Among the metatexites, only stromatites are recognized (Fig. 3C). The stromatic layering is generally parallel to the main foliation of the metasedimentary rocks. Leucosomes are between 0.3 and $2 \mathrm{~cm}$ thick. These rocks are composed of three parts: 1) a dark grey part with similar characteristics to the metasedimentary rocks. This would represent the mesosome; 2) A white part containing quartz, plagioclase and K-feldspar. This part represents the leucosome of the metatexite and has a welldeveloped medium grained granular texture; 3) A black part, which is formed mainly by biotite. These biotite crystals are larger and more abundant than those observed in the mesosome. Also, this sector is enriched in accessory minerals such as apatite and zircon. It is located next to the leucosomes and represents melanosomes.

The common mineral assemblage of the mesosomes is defined by $\mathrm{Qtz}+\mathrm{Pl}+\mathrm{Bt}+\mathrm{Ms}+\mathrm{Crd} \pm \mathrm{Sil}$ (fibrolite) \pm Kfs. A single sample was found where the mineral assemblage for mesosome was $\mathrm{Qtz}+\mathrm{Pl}+\mathrm{Bt}+\mathrm{Grt}$. In this case garnets constitute poikiloblasts with numerous inclusions of quartz. Melanosomes in this sample are formed by biotite and cordierite where biotites reach $1.5 \mathrm{~cm}$ of length. Near the contact with leucosomes, garnets are fragmented and most of them show a plagioclase rim. 


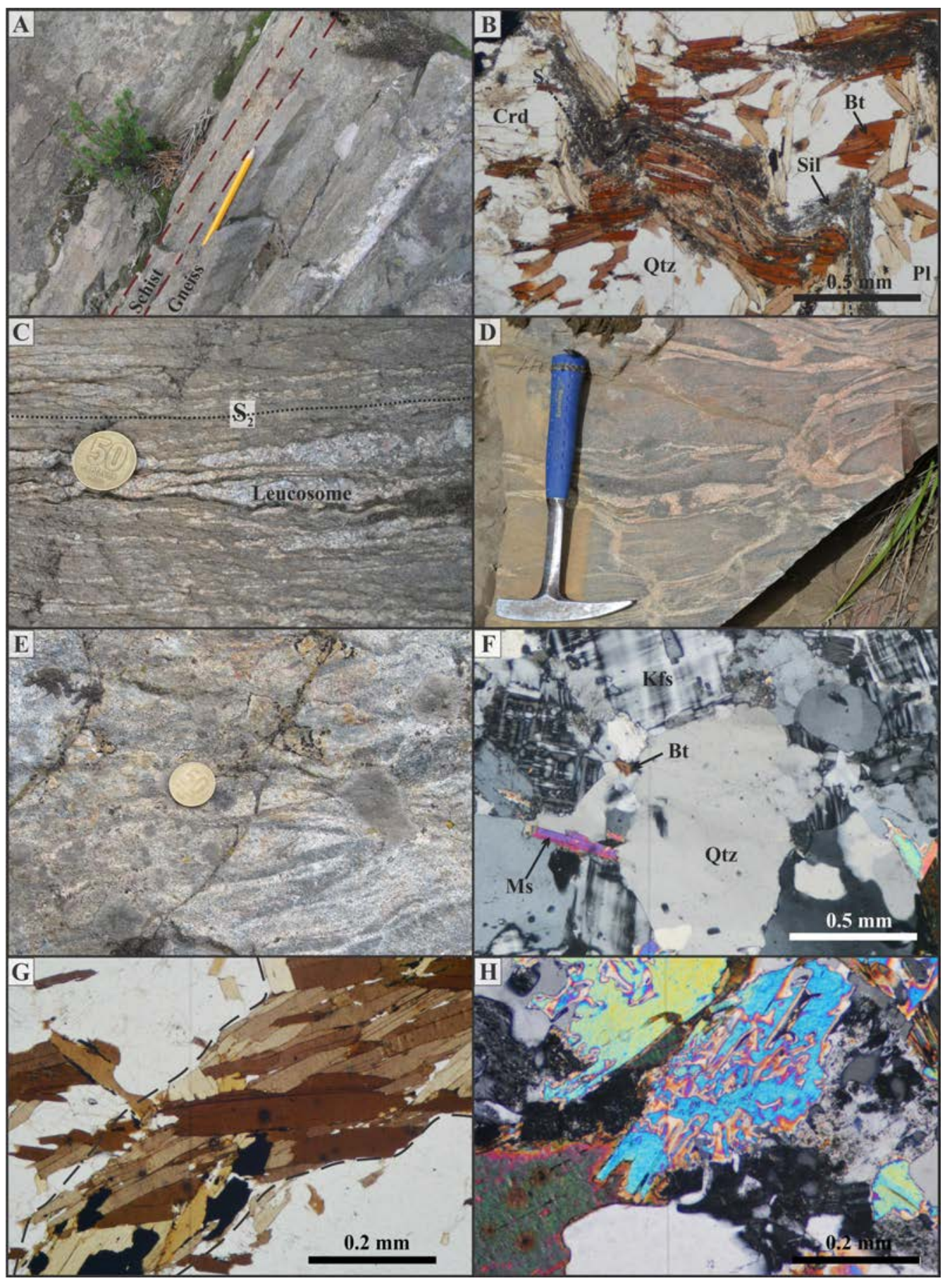

FIG. 3. Field photographs and photomicrographs showing the metasedimentary rocks and migmatites from San Martín de los Andes area. A. Alternate gneisses and schists; $\mathbf{B}$. Main metamorphic assemblage in schists $\mathrm{Qtz}+\mathrm{Pl}+\mathrm{Bt}+\mathrm{Crd}+\mathrm{Sil}$ defining the crenulated $\mathrm{S}_{2}$ foliation; C. Stromatic structure in a metatexite. Note the stromatic layering is parallel to the principal foliation $\left(\mathrm{S}_{2}\right)$ of the metasedimentary rocks; D. Schollen diatexites. Rafts of metasedimentary rocks with incipient migmatization; E. Schlieren diatexites with flow banding structure with aligned biotite schlierens; F. Photomicrography of the leucosome of a schollen diatexite with quartz, microcline, plagioclase, biotite and muscovite; G. Photomicrography of a schlieren in thin section defined by dotted line; H. Symplectites between muscovite and quartz. All mineral abreviations according to Siivola and Schmid (2007). 


\subsection{Diatexite migmatites}

Two types of diatexites can be recognized in the surroundings of San Martín de los Andes: schollen and schlieren diatexites (Fig. 3D and E). The first type has well defined leucosomes with a dominant igneous texture and coarse grains. Leucosomes contain quartz, microcline and plagioclase in high proportion and biotite, muscovite in low proportion (Fig. 3F). These leucosomes have the highest percentage of K-feldspar. Mesosomes are found as rafts of metasedimentary rocks with incipient migmatization. Mafic selvedges are frequently developed between mesosomes and leucosomes. Frequently in the contact between mesosome and leucosome, mafic selvedges are developed. They are only a few micrometer thin and are composed of biotites and quartz with large amount of accessory minerals such as zircons and Fe-Ti oxides. Crystals of biotite tend to follow the main orientation of the mesosome although discrete folds can be recognized in some sectors. They are interpreted as the result of deformation during leucosome growth (Sawyer, 2008). Schlieren diatexites contain $\mathrm{Bt}+\mathrm{Pl}+\mathrm{Qtz}+\mathrm{Crd} \pm \mathrm{Ms}$. Schlierens are composed by biotite and ilmenite (Fig. 3G). They present flow banding where the biotite schlierens are aligned. These rocks present a well-developed granoblastic texture. Both in schlieren and schollen leucosomes is common to find myrmekites as an intergrowth of quartz and $\mathrm{K}$-feldspar. It is also common to find poikilitic crystals of feldspar and plagioclases containing rounded inclusions of quartz and biotites. These microstructures have been identified as representing different stages on melt crystallization (Sawyer, 2008). Finally, symplectites between micas (muscovite and biotite) and quartz are recognized (Fig. 3H).

\subsection{Anatectic granites}

In the southern shore of Lago Lácar, within the westernmost outcrop of high-grade metamorphic rocks, we identified a small and deformed plutonic body, which we consider an anatectic granite. This rock is coarse-grained, with quartz, plagioclase, $\mathrm{K}$-feldspar and biotite as primary minerals and apatites and zircons as accessory minerals. K-feldspars and plagioclases are pseudomorphically replaced by sericite. Biotites are replaced by chlorite, epidote and prehnite. Intracrystalline deformation is common in quartz with microstructures such as undulatory extinction, chessboard subgrains and static recrystallization (Fig. 4A).

This granite presents a transitional contact with schists. Next to the plutonic body, a sector rich in biotite is found. These biotites are larger than the ones in the granite and are associated to epidote. The sequence continues with schistose rocks containing a mineral paragenesis of $\mathrm{Bt}+\mathrm{Pl}+\mathrm{Qtz}+\mathrm{Hbl}+\mathrm{Ep}$. As accessory phases, zircons and monazite are found. Allanite with epidote rims is found as inclusions in biotite (Fig. 4B).

\subsection{Devonian plutonic rocks}

Granodiorites are the most abundant Devonian igneous rocks. They are light grey with mediumcoarse grained equigranular texture, including plagioclase, quartz, K-feldspar, biotite and hornblende as main minerals. Perthitic feldspar is common and myrmekites are present in some places where quartz is intergrown with feldspar. Apatite, zircon and titanite have been recognized as accessory minerals.

Tonalites are dark grey with medium grained equigranular texture. Zoned plagioclase, quartz, hornblende, $\mathrm{K}$-feldspar and biotite (this last two in minor proportion) are the main minerals. Within accessory minerals, apatite and zircon are the most common. The contact between granodiorites and tonalites is transitional and these lithological variations could represent compositional and textural variations of the same magmatic event.

Gabbros are scarce and show a transitional contact with the main plutonic rocks. They are dark green with medium grained equigranular texture. The primary minerals include plagioclase, hornblende and pyroxene.

In all these rocks, magmatic mineral assemblages are commonly replaced by a secondary paragenesis (Fig. 4C). Plagioclase is pseudomorphically replaced by sericite and clay minerals. Prehnite and chlorite are found replacing biotite, and epidote is usually found parcially replacing both biotite and hornblende. In gabbros, hornblende is partially replaced by actinolite and chlorite, and plagioclase is replaced by sericite. Some crystals often display intracrystalline deformation. Quartz crystals present undulatory extintion and chessboard subgrains and biotites present kinking. 


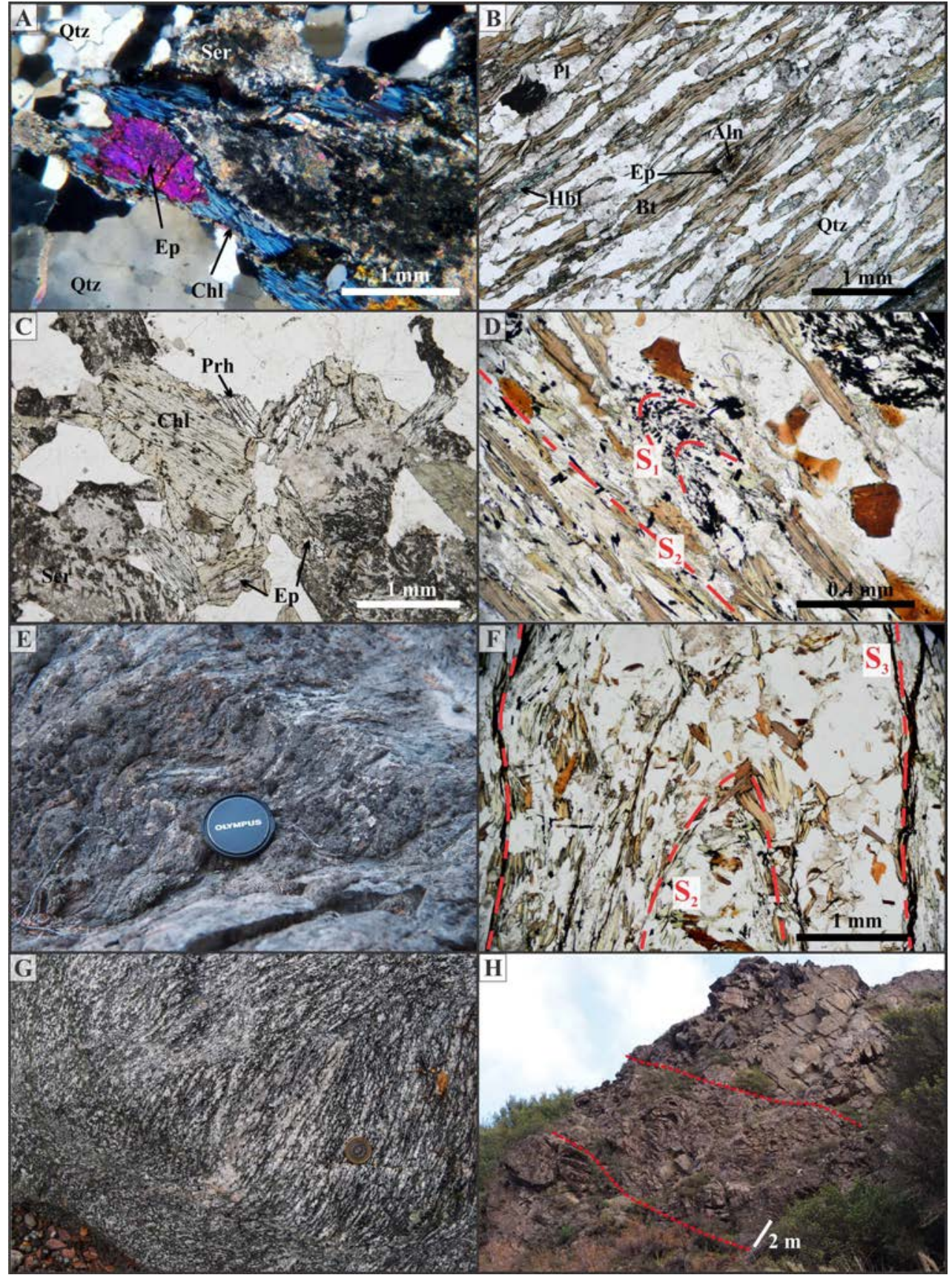

FIG. 4. Field photographs and microphotographs of Devonian granitoids and metamorphic rocks, and structures from San Martin de los Andes area. A. Secondary paragenesis and microstructures in the anatectic granite; B. Microphotograph of the schist from the country rock of the anatectic granite, showing the $\mathrm{S}_{2}$ regional foliation; C. Low-grade metamorphic paragenesis in Devonian granitoids; D. Photomicrograph of a biotite-rich schist with $\mathrm{S}_{2}$ foliation and relict $\mathrm{S}_{1}$ foliation defined mainly by graphite; E. Field photograph of $\mathrm{S}_{2}$ affected by $\mathrm{D}_{3}$ crenulation; F. Photomicrography of folded $\mathrm{S}_{2}$ and incipient $\mathrm{S}_{3}$ crenulation cleavage defined by opaque minerals along pressure-solution bands; G. Discrete centimetric brittle-ductile shear bands affecting Devonian igneous rocks; H. Oblique section of the Alerce river Gondwanan brittle-ductile thrust (Gondwanan shear band), affecting Devonian tonalites near Lago Curruhué Chico (see location in figure 2B). Top block with NE tectonic transport direction. All mineral abreviations according to Siivola and Schmid (2007). 


\section{Structure}

At least three different tectonic foliations can be recognized in the high-grade metamorphic rocks. The pervasive regional foliation observed in the high-grade metamorphic rocks is defined by the orientation of minerals related to the metamorphic peak (Fig. 3B). It appears in thin section as a spaced schistosity in gneisses and as continuous schistosity in schists (Passchier and Trouw, 2005). Incipient migmatization and leucosomes from metatexites are concordant with this foliation (Fig. 3C), while in diatexites the abundant melt extracted cut it. This implies that the migmatization occurred synto post- development of the regional foliation. Major structures related to this foliation cannot be recognized in the region due to the scarcity of the outcrops. We consider that this regional foliation is most likely an $\mathrm{S}_{2}$, since remnants of an early foliation $\left(\mathrm{S}_{1}\right)$ are discernible in some samples (Fig. 4D). The $\mathrm{S}_{2}$ foliation is affected by a later stage of folding that produced crenulation folds and a local incipient crenulation cleavage $\left(\mathrm{S}_{3}\right)$, defined by the alignment of opaque minerals along discontinuous pressuresolution bands (Fig. 4E and F).

The Devonian igneous rocks commonly show magmatic foliation and are affected by discrete centimetric to hectometric brittle-ductile shear zones (Fig. 4G), mostly found in the granodiorites and tonalites. Two thick shear bands, named Pinos river and Alerce river shear bands (Fig, 2B), are found in the surroundings of lake Curruhué. The Pinos river shear band is $200 \mathrm{~m}$ thick, while the Alerce river shear band shows a thickness between $15 \mathrm{~m}$ and $35 \mathrm{~m}$
(Fig. 4H and 5A). Both of them display a NNW-SSE trend, dip to WSW and tectonic transport of the hanging-wall towards the ENE. This brittle-ductile deformation event that affected the Devonian rocks is clearly post-Famatinian and could be related to the Gondwanan orogenic cycle.

Finally, several folds and faults are found in the studied area, which affect the igneous-metamorphic basement and also the Mesozoic and Cenozoic volcanic-sedimentary cover. They are easily differentiated from the previously described structures, since they were formed under non-metamorphic conditions. These structures are mainly reverse faults, thrusts and open folds, related to a N-S to NNW-SSE trending Andean thrust and fold belt (Folguera et al., 2011; Fig. 5B). In the studied area, the main structures of the Andean cycle are the Lacar and Curruhué thrusts, which dip towards the ENE and WSW, respectively. The trend and dip of these Andean thrust approximately coincide with that of the Gondwanan shear bands of its sourroundings, which could indicate a possible Palaeozoic (Gondwanan) inheritance of these Cenozoic structures.

\section{Whole rock geochemistry of pre-Devonian basement rocks}

Major, trace and Rare Earth Elements (REE) contents have been determined on eight rock samples: 2 samples correspond to metasedimentary rocks (Samples SMA86 and SMA86a); 2 samples are metatexites (SMA96 and SMA98); 2 samples correspond to schlieren diatexites (SMA 89a and SMA84); 1 sample is a leucosome from the schollen

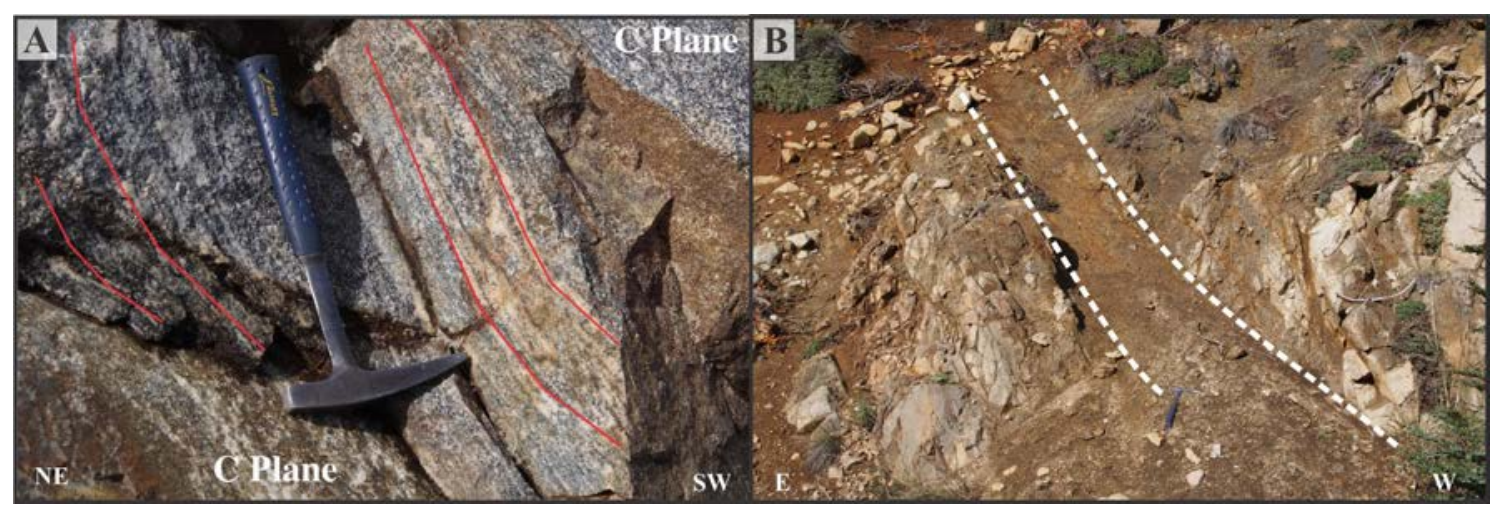

FIG. 5. A. Detail of the río Alerce shear band, showing C and S structures in red; B. Andean brittle fault. 
diatexite (SMA89) and 1 sample is an anatectic granite (SMA74) (location in figure 2A).

$15 \mathrm{~g}$ of whole rock powders were sent to ACME Analytical Laboratories S.A. Samples were prepared by alkaline fusion with lithium borate, diluted with acid digestion to perform ICP-MS method. Major element data were recalculated to $100 \%$ on anhydrous basis before using them in the geochemical characterization and classification. Results are shown in table 1.

\subsection{Major elements}

Metasedimentary rocks display high contents of $\mathrm{SiO}_{2}(>70 \%)$. The Aluminum Saturation Index (ASI) for these rocks is greater than 1 and alkalis content $\left(\mathrm{Na}_{2} \mathrm{O}+\mathrm{K}_{2} \mathrm{O}\right)$ ranges between 3.8 and 4.6 with $\mathrm{Na}_{2} \mathrm{O}$ $>\mathrm{K}_{2} \mathrm{O}$. According to their contents in $\mathrm{SiO}_{2}, \mathrm{Al}_{2} \mathrm{O}_{3}$, $\mathrm{Fe}_{2} \mathrm{O}_{3}, \mathrm{~K}_{2} \mathrm{O}$ and $\mathrm{Na}_{2} \mathrm{O}$ these rocks are classified as metagreywackes (Herron, 1988).

Compared to the metasedimentary rocks the metatexites and schlieren diatexites are enriched in $\mathrm{Al}_{2} \mathrm{O}_{3}, \mathrm{Fe}_{2} \mathrm{O}_{3}, \mathrm{MgO}, \mathrm{CaO}, \mathrm{K}_{2} \mathrm{O}$ and $\mathrm{TiO}_{2}$. This is especially noticeable in sample SMA98, which has a biotite-rich melanosome.

The geochemical signature of the leucosome from the schollen diatexite (sample SMA89) differs from the other samples. It is depleted in $\mathrm{Fe}_{2} \mathrm{O}_{3}, \mathrm{TiO}_{2}, \mathrm{MgO}, \mathrm{CaO}$ and $\mathrm{MnO}$. Meanwhile, the anatectic granite exhibits an increase in $\mathrm{Al}_{2} \mathrm{O}_{3}$ and $\mathrm{K}_{2} \mathrm{O}$, and has high contents of $\mathrm{CaO}, \mathrm{Fe}_{2} \mathrm{O}_{3}$ and $\mathrm{MgO}$. Following the normative (Ab-An-Or) classification for felsic plutonic rocks proposed by (Barker, 1979), the anatectic granite and the leucosome samples plot as granodiorite and trondhjemite, respectively. Both samples plot in the peraluminous field of Shand (1943).

\subsection{REE and trace elements}

Two groups of samples can be distinguished according to their differences in chemical composition: one group includes metasedimentary rocks, metatexites and diatexites samples, and the other one includes the leucosome and anatectic granite. This last group shows significant differences regarding the first one, being the Sc depletion and the average total REE contents the most remarkable ones. Leucosome and anatectic granite have 8 times lower average REE contents than migmatites and metasedimentary rocks. Moreover, the analyzed leucosome is depleted in $\mathrm{Ba}$ and $\mathrm{Sr}$ and enriched in $\mathrm{Rb}$, in contrast with the metasedimentary rocks, while the anatectic granite is depleted in $\mathrm{Ba}$ and enriched in $\mathrm{Rb}$ and $\mathrm{Sr}$.

Metatexites, schlieren diatexites and metasedimentary rocks present a similar multielement distribution pattern normalized to the Primitive Mantle (Sun and McDonough, 1989) and chondrite normalized REE pattern, normalized to the C1chondrite after Sun and McDonough (1989) (Fig. 6). The REE patterns (Fig. 6A) are enriched in light REE (LREE) with $(\mathrm{La} / \mathrm{Lu})_{\mathrm{N}}$ ratios between 6.8 and 10.4, and all of them display a negative Eu anomaly $(\mathrm{Eu} /$ $\mathrm{Eu}^{*}=0.50-0.80$ ). Multielement patterns (Fig. 6B) are depleted in $\mathrm{Ba}, \mathrm{Nb}, \mathrm{Ta}, \mathrm{Sr}, \mathrm{P}$ and $\mathrm{Ti}$.

On the other hand, the leucosome and the anatectic granite display lower total REE contents compared with the other samples. The chondrite normalized REE pattern shows similar values of LREE and heavy REE. They have $(\mathrm{La} / \mathrm{Lu})_{\mathrm{N}}$ ratios between 1.71 y 2.45 and a positive $\mathrm{Eu}$ anomaly $\left(\mathrm{Eu} / \mathrm{Eu}^{*}=\right.$ 1.50-1.65). Regarding the multielement pattern, they have marked negative anomalies for $\mathrm{Th}, \mathrm{Nb}$, $\mathrm{Ta}, \mathrm{La}, \mathrm{Ce}, \mathrm{Pr}$ and Ti. The leucosome shows high $\mathrm{Rb} / \mathrm{Sr}$ ratio (0.71) and the $\mathrm{Sr} / \mathrm{Ba}$ ratio is relatively low (0.35). Meanwhile, the anatectic granite has low $\mathrm{Rb} / \mathrm{Sr}$ (0.39) and relatively high $\mathrm{Sr} / \mathrm{Ba}$ (1.1).

\section{U-Pb zircon ages of high-grade metamorphic rocks and anatectic granites}

Zircon grains were obtained from a metasedimentary rock sample (Serra-Varela et al., 2016) and the anatectic granite (sample SMA74). Standard jawcrushing, sieving and heavy mineral concentration by hydraulic processes and magnetic susceptibility techniques were performed at the laboratories of the Instituto de Paleobiología y Geología (Universidad Nacional de Río Negro). Zircon grains were handpicked under binocular microscope. About two hundred grains were selected for each sample from the non-magnetic fraction. One hundred and fifty of these grains were mounted in epoxy resin and polished. Backscattered electron images (BSE) were obtained with a JEOL JSM 5600 scanning electron microscope of the Universidad de Oviedo, in order to assess the internal morphology, prior to the U-Pb laser work. Additionally, zircons that were not mounted for dating were imaged by BSE using a Zeiss Evo MA15 scanning electron microscope at Universidad Nacional de Río Negro, in order to examine the external morphology of the grains. 
TABLE 1. GEOCHEMICAL ANALYSIS RESULTS FOR MAJOR, TRACE AND RARE EARTH (REE) ELEMENTS OF THE SAMPLES. MAJOR ELEMENTS IN WT\%, TRACE ELEMENTS IN PPM.

\begin{tabular}{|c|c|c|c|c|c|c|c|c|}
\hline & \multicolumn{2}{|c|}{ Metasedimentary rocks } & \multicolumn{2}{|c|}{ Metatexites } & \multicolumn{2}{|c|}{ Schlieren diatexites } & \multirow{2}{*}{$\begin{array}{c}\begin{array}{c}\text { Diatexite } \\
\text { leucosome }\end{array} \\
\text { SMA } 89\end{array}$} & \multirow{2}{*}{$\begin{array}{c}\begin{array}{c}\text { Anatectic } \\
\text { granite }\end{array} \\
\text { SMA } 74\end{array}$} \\
\hline & SMA 86 & SMA 86a & SMA 96 & SMA 98 & SMA 84 & SMA 89a & & \\
\hline & $40^{\circ} 7{ }^{\prime} 5 \% \mathrm{~S}$ & $40^{\circ} 7^{\prime} 51.7^{\prime \prime S}$ & $40^{\circ} 10^{\prime} 57^{\prime} \mathrm{S}$ & $40^{\circ} 10 ’ 32 \% \mathrm{~S}$ & 409'27’S & 407'54"S & $40^{\circ} 7{ }^{\prime} 52.6 ” S \mathrm{~S}$ & $40^{\circ} 10^{\prime} 53 ” \mathrm{~S}$ \\
\hline & $71^{\circ} 21^{\prime} 52^{\prime \prime} \mathrm{W}$ & 71'21'51"W & $71^{\circ} 21^{\prime} 25^{\prime \prime} \mathrm{W}$ & 71'21'29"W & 71'20’39”'W & 71'22’30”W & 71'22’29.3”W & $71^{\circ} 23^{\prime} 27^{\prime \prime} \mathrm{W}$ \\
\hline $\mathrm{SiO}_{2}$ & 72.10 & 73.24 & 72.19 & 55.04 & 68.78 & 73.73 & 75.54 & 62.06 \\
\hline $\mathrm{Al}_{2} \mathrm{O}_{3}$ & 12.17 & 11.24 & 11.78 & 17.12 & 12.91 & 12.33 & 13.88 & 16.35 \\
\hline $\mathrm{Fe}_{2} \mathrm{O}_{3}$ & 5.41 & 5.24 & 5.59 & 10.33 & 6.82 & 4.04 & 0.22 & 5.77 \\
\hline $\mathrm{MgO}$ & 1.78 & 1.62 & 1.73 & 4.11 & 2.22 & 1.4 & 0.07 & 2.51 \\
\hline $\mathrm{CaO}$ & 1.58 & 1.37 & 1.61 & 3.12 & 1.61 & 1.74 & 0.99 & 4.42 \\
\hline $\mathrm{Na}_{2} \mathrm{O}$ & 2.57 & 2.17 & 2.17 & 2.11 & 2.1 & 3.53 & 2.93 & 2.64 \\
\hline $\mathrm{K}_{2} \mathrm{O}$ & 1.95 & 1.58 & 2.26 & 3.8 & 2.74 & 1.77 & 5.27 & 2.51 \\
\hline $\mathrm{TiO}_{2}$ & 0.80 & 0.89 & 0.95 & 1.32 & 1.09 & 0.71 & 0.03 & 0.59 \\
\hline $\mathrm{P}_{2} \mathrm{O}_{5}$ & 0.14 & 0.15 & 0.19 & 0.13 & 0.18 & 0.07 & 0.08 & 0.17 \\
\hline $\mathrm{MnO}$ & 0.06 & 0.06 & 0.05 & 0.13 & 0.07 & 0.04 & $<0.01$ & 0.08 \\
\hline $\mathrm{Cr}_{2} \mathrm{O}_{3}$ & 0.009 & 0.009 & 0.009 & 0.023 & 0.013 & 0.008 & 0.003 & 0.006 \\
\hline LOI & 1.2 & 2.2 & 1.2 & 2.4 & 1.2 & 0.4 & 0.8 & 2.7 \\
\hline Sum & 99.8 & 99.8 & 99.74 & 99.66 & 99.74 & 99.78 & 99.84 & 99.81 \\
\hline $\mathrm{Sc}$ & 12 & 11 & 12 & 26 & 16 & 11 & 1 & 7 \\
\hline $\mathrm{Ba}$ & 400 & 313 & 472 & 860 & 574 & 469 & 287 & 306 \\
\hline $\mathrm{Be}$ & $<1$ & $<1$ & $<1$ & 1 & $<1$ & $<1$ & $<1$ & 2 \\
\hline Co & 47.9 & 41.8 & 50.1 & 39.5 & 34.7 & 30.1 & 35.2 & 48.2 \\
\hline Cs & 3.8 & 2.4 & 3.5 & 7.7 & 4.7 & 3.3 & 0.2 & 4.2 \\
\hline $\mathrm{Ga}$ & 14.5 & 13.9 & 13.1 & 21.3 & 15.5 & 10.3 & 6.5 & 16.2 \\
\hline $\mathrm{Hf}$ & 5.5 & 8.8 & 10.1 & 9.7 & 8 & 6.6 & 0.5 & 3.2 \\
\hline $\mathrm{Nb}$ & 13.5 & 14.3 & 13.5 & 16.4 & 16.1 & 9 & 1.6 & 9.4 \\
\hline $\mathrm{Rb}$ & 76.8 & 61.3 & 91.9 & 152.5 & 107.3 & 75.1 & 72.8 & 120.6 \\
\hline $\mathrm{Sn}$ & 2 & 2 & 1 & 2 & 3 & $<1$ & $<1$ & 1 \\
\hline $\mathrm{Sr}$ & 171.5 & 125.5 & 152.5 & 278.5 & 135.7 & 170.7 & 103 & 309.5 \\
\hline $\mathrm{Ta}$ & 0.8 & 0.9 & 0.7 & 1.3 & 1 & 0.7 & 0.4 & 0.5 \\
\hline Th & 8.6 & 8.7 & 8.6 & 13.3 & 11 & 6.8 & 0.7 & 1.1 \\
\hline $\mathrm{U}$ & 2.3 & 2.4 & 2.2 & 2.6 & 2.4 & 2 & 2.2 & 0.7 \\
\hline V & 93 & 90 & 95 & 228 & 118 & 81 & $<8$ & 141 \\
\hline
\end{tabular}


table 1 continued.

\begin{tabular}{|c|c|c|c|c|c|c|c|c|}
\hline & \multicolumn{2}{|c|}{ Metasedimentary rocks } & \multicolumn{2}{|c|}{ Metatexites } & \multicolumn{2}{|c|}{ Schlieren diatexites } & \multirow{2}{*}{$\begin{array}{c}\begin{array}{c}\text { Diatexite } \\
\text { leucosome }\end{array} \\
\text { SMA } 89\end{array}$} & \multirow{2}{*}{$\begin{array}{c}\begin{array}{c}\text { Anatectic } \\
\text { granite }\end{array} \\
\text { SMA } 74\end{array}$} \\
\hline & SMA 86 & SMA 86a & SMA 96 & SMA 98 & SMA 84 & SMA 89a & & \\
\hline & 407'52"S & $40^{\circ} 7 ' 51.7 ’ \mathrm{~S}$ & $40^{\circ} 10 ’ 57 ’ \mathrm{~S}$ & $40^{\circ} 10^{\prime} 32 ” \mathrm{~S}$ & 409’27’S & 407'54”S & 407'52.6"S & $40^{\circ} 10^{\prime} 53 ” S$ \\
\hline & 71'21'52”W & $71^{\circ} 21^{\prime} 51^{\prime} \mathrm{W}$ & $71^{\circ} 21^{\prime} 25 " \mathrm{~W}$ & 71'21'29”W & $71^{\circ} 20^{\prime} 39 ” W$ & $71^{\circ} 22^{\prime} 30^{\prime} \mathrm{W}$ & $71^{\circ} 22^{\prime} 29.3 ” W$ & $71^{\circ} 23$ '27' W \\
\hline W & 229.8 & 187.6 & 255.1 & 71.6 & 157.4 & 200 & 350.5 & 155.6 \\
\hline $\mathrm{Zr}$ & 196.6 & 342.9 & 373.9 & 337.6 & 301.1 & 253.7 & 14.7 & 115.4 \\
\hline Y & 29.9 & 34 & 31.5 & 19.9 & 35.2 & 23.6 & 8.4 & 7.7 \\
\hline $\mathrm{La}$ & 33.7 & 35.5 & 31.6 & 38.9 & 39.5 & 23.5 & 3.5 & 3.2 \\
\hline $\mathrm{Ce}$ & 72.9 & 76.6 & 71.9 & 83 & 83.5 & 50.1 & 6 & 7.1 \\
\hline $\operatorname{Pr}$ & 8.22 & 8.44 & 8.19 & 9.52 & 9.98 & 6.16 & 0.83 & 0.98 \\
\hline $\mathrm{Nd}$ & 32.9 & 32.8 & 32 & 37.1 & 38.1 & 24.2 & 3 & 4.6 \\
\hline $\mathrm{Sm}$ & 6.15 & 6.75 & 6.46 & 6.92 & 7.75 & 4.87 & 0.84 & 1.45 \\
\hline $\mathrm{Eu}$ & 1.65 & 1.52 & 1.29 & 1.05 & 1.45 & 1.18 & 0.48 & 0.77 \\
\hline $\mathrm{Gd}$ & 6.14 & 6.73 & 6.32 & 5.78 & 7.45 & 4.78 & 1.12 & 1.42 \\
\hline $\mathrm{Tb}$ & 0.94 & 1.04 & 1.03 & 0.78 & 1.17 & 0.73 & 0.24 & 0.21 \\
\hline Dy & 5.72 & 6.01 & 6.22 & 4.02 & 6.64 & 4.5 & 1.63 & 1.24 \\
\hline Но & 1.11 & 1.23 & 1.23 & 0.77 & 1.27 & 0.84 & 0.29 & 0.26 \\
\hline $\mathrm{Er}$ & 3.27 & 3.65 & 3.44 & 2.21 & 3.69 & 2.66 & 0.96 & 0.69 \\
\hline $\mathrm{Tm}$ & 0.46 & 0.53 & 0.54 & 0.34 & 0.54 & 0.36 & 0.17 & 0.1 \\
\hline $\mathrm{Yb}$ & 3.21 & 3.36 & 3.68 & 2.37 & 3.72 & 2.42 & 1.43 & 0.76 \\
\hline $\mathrm{Lu}$ & 0.49 & 0.52 & 0.54 & 0.4 & 0.56 & 0.37 & 0.22 & 0.14 \\
\hline $\mathrm{Ni}$ & 33.3 & 31.1 & 29 & 65.4 & 37.4 & 23.9 & 1.1 & 11.9 \\
\hline
\end{tabular}

U-Pb analyses were performed in SGIker Institute (Universidad del País Vasco) using a quadrupole mass spectrometer with inductively coupled plasma source (Q-ICP-MS) Thermo Fisher Scientific, XSeries-II model coupled to a New Wave UP213 laser ablation system. Laser spot size was $30 \mu \mathrm{m}$. Data were acquired during a 30 seconds background measurement followed by 60 seconds ablation of the sample. Laser-induced elemental fractionation and instrumental mass discrimination were corrected by normalization to the reference zircon GJ-1 (Jackson et al., 2004) as primary standard, and Plesovice reference zircon as secondary standard (Sláma et al., 2008). The measure sequence among standard- sample is a standard followed by 5 unknowns. For data treatment, we use the Iolite 3 software (Paton et al., 2011) and VizualAge (Petrus and Kamber, 2012). Age calculation and plots were made using ISOPLOT software (Ludwig, 2003). For further details of the analytic procedures see Puelles et al. (2014). All analytical errors are presented as absolute values at $2 \sigma$ level (Results in table 2 and 3 ).

\subsection{Detrital zircon age}

In this section, data from Serra-Varela et al. (2016) will be re-evaluated. On the basis of shape, habit and aspect ratios, different zircon groups were identified 


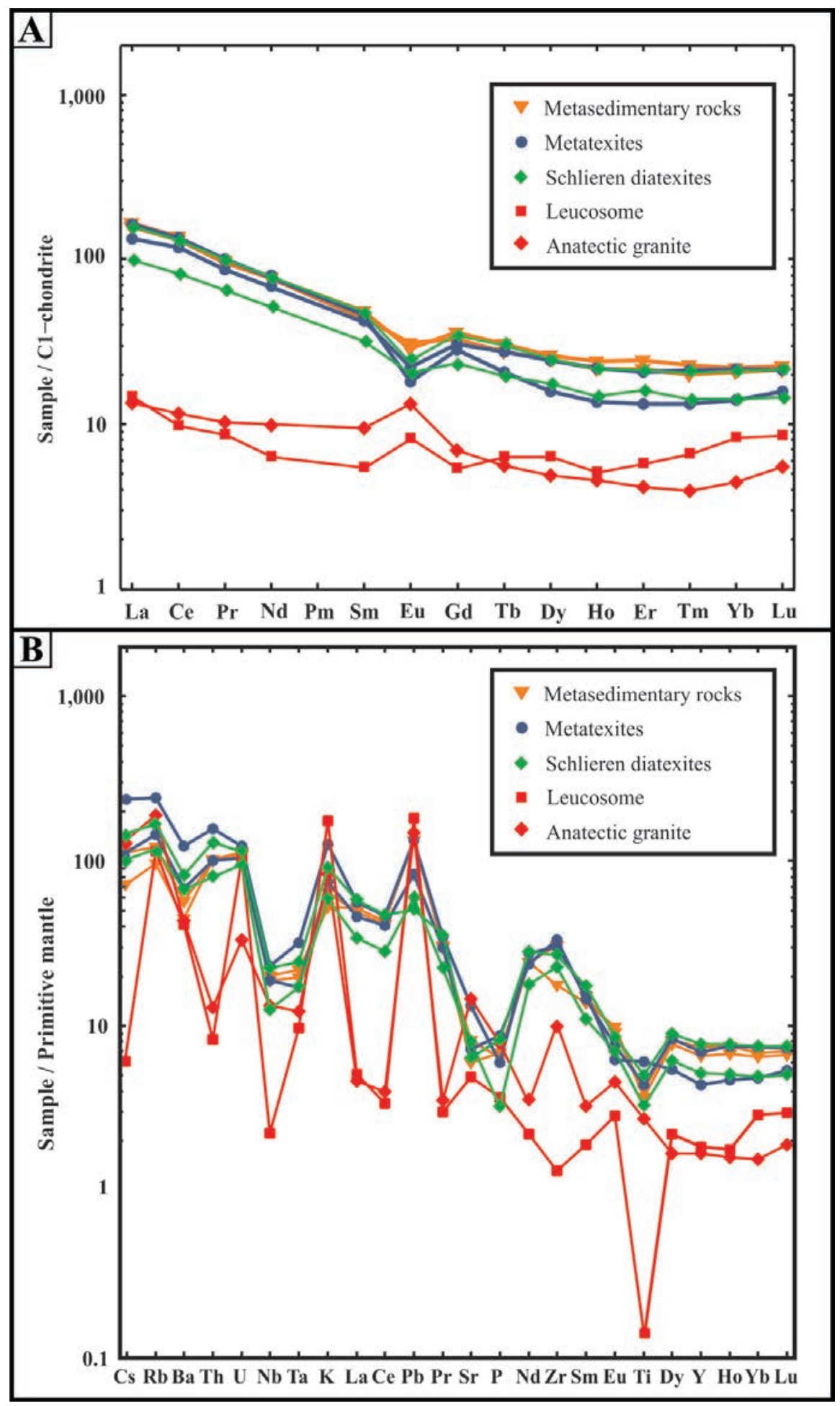

FIG. 6. A. Chondrite normalized Rare Earth Elements diagram of metamorphic rock samples from San Martín de los Andes area. Chondrite REE contents after Sun and McDonough (1989); B. Primitive mantle normalized incompatible element abundances (after Sun and McDonough, 1989) of metamorphic rock samples from San Martín de los Andes area. 


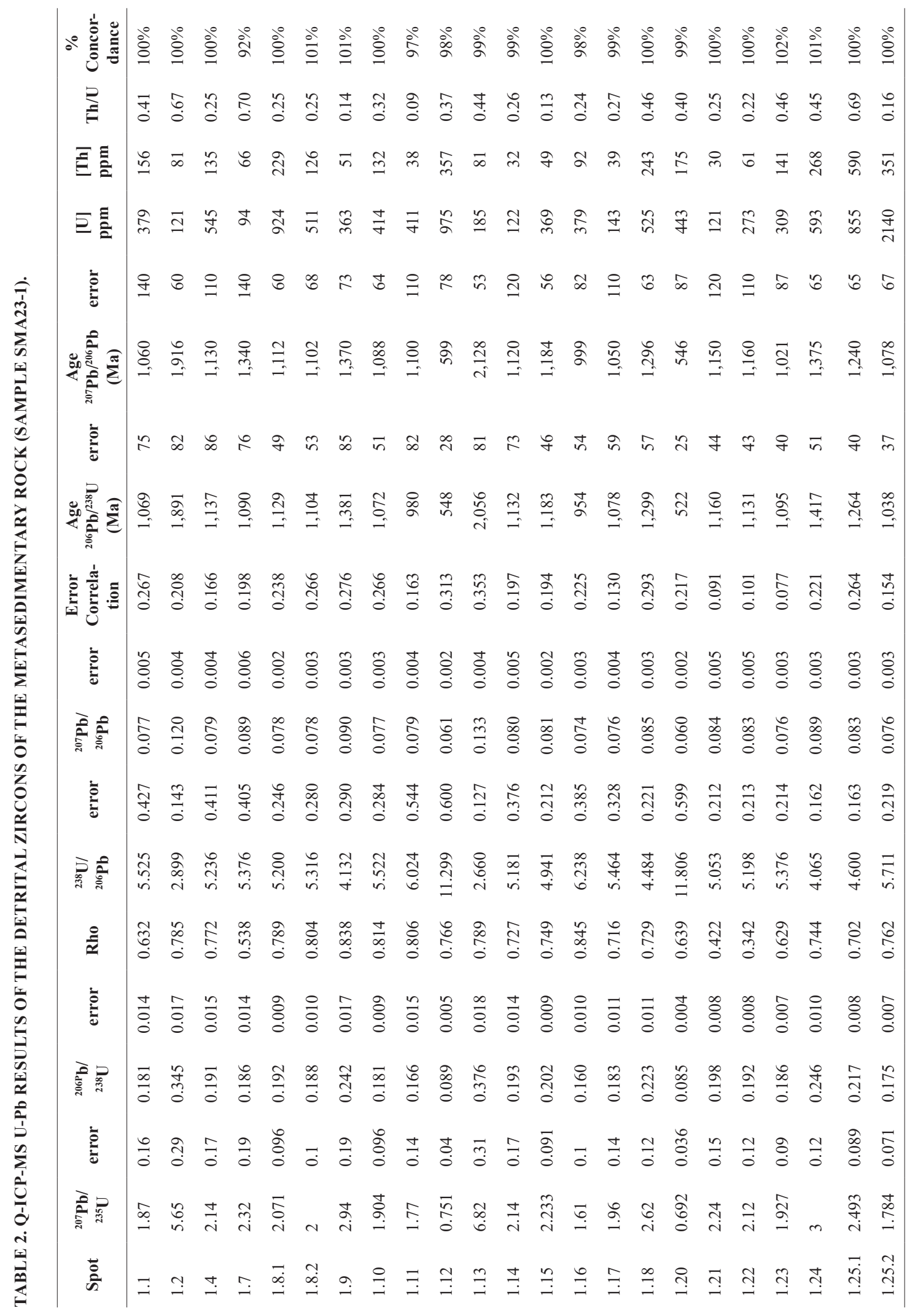




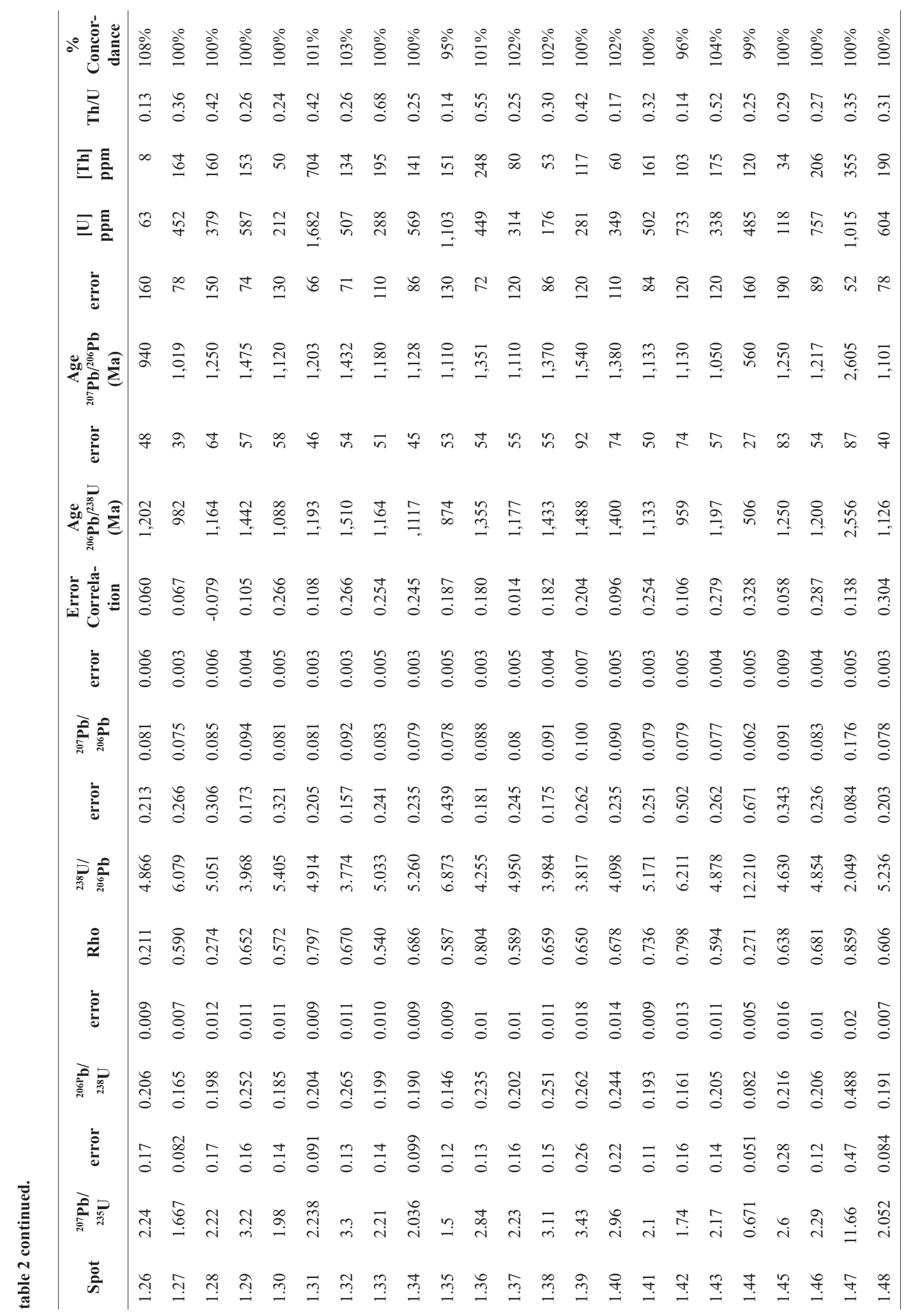




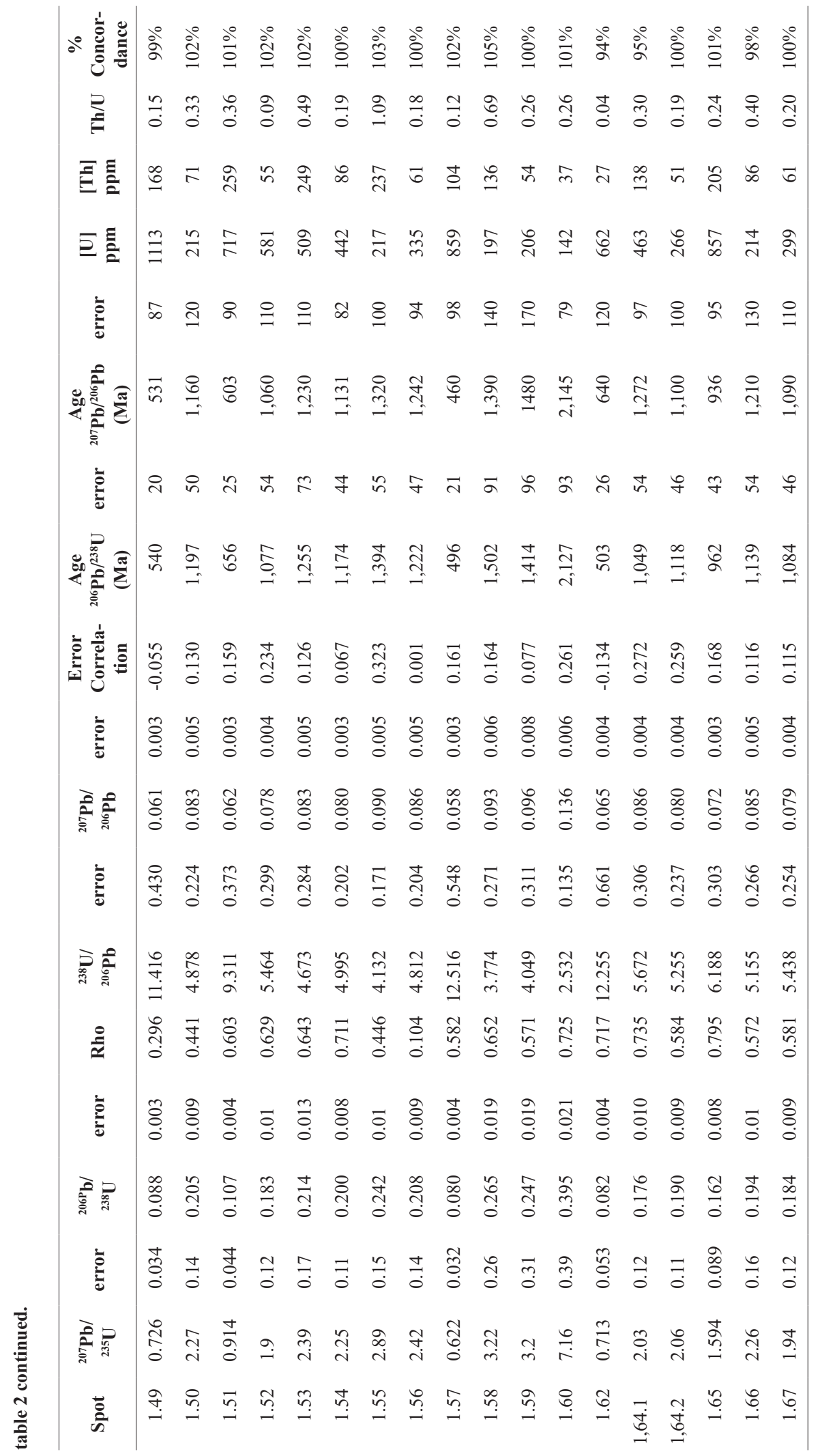




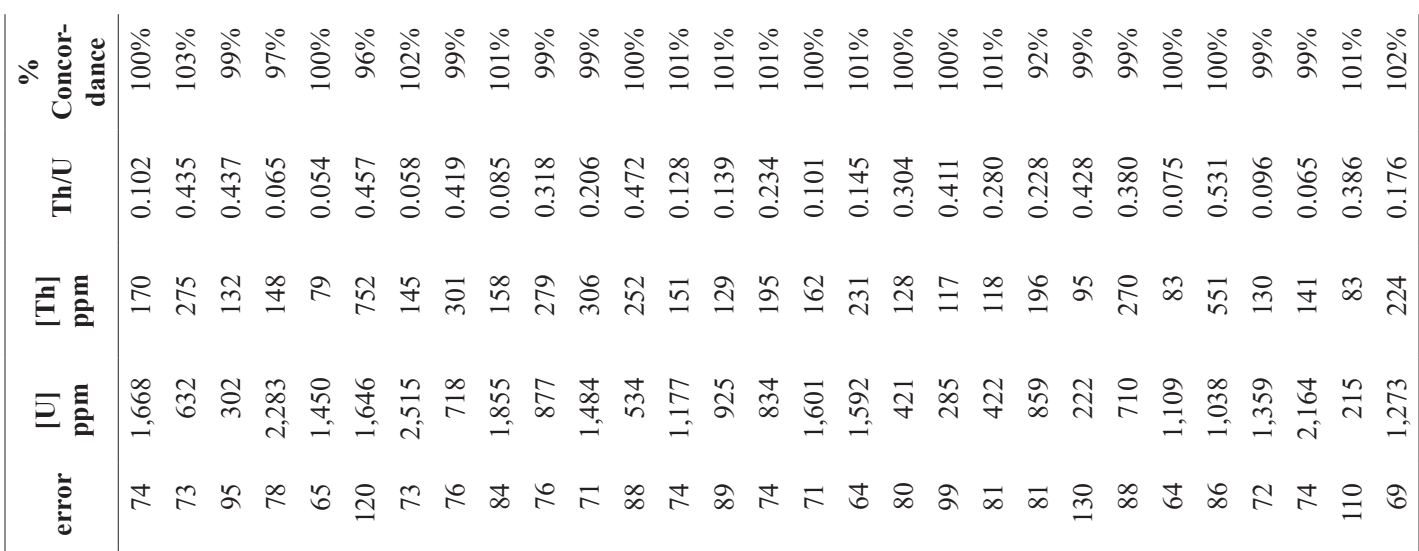

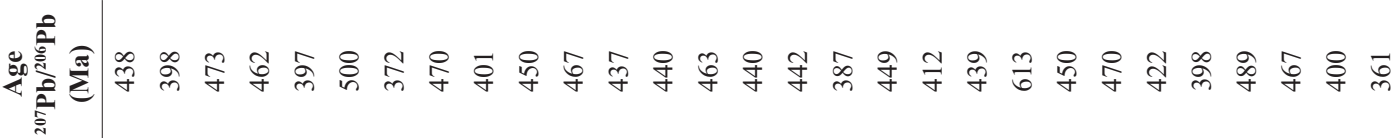

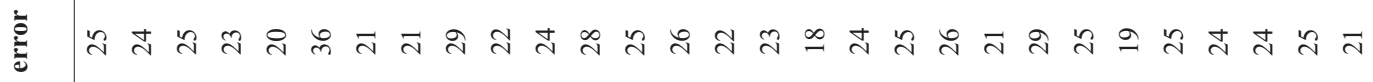

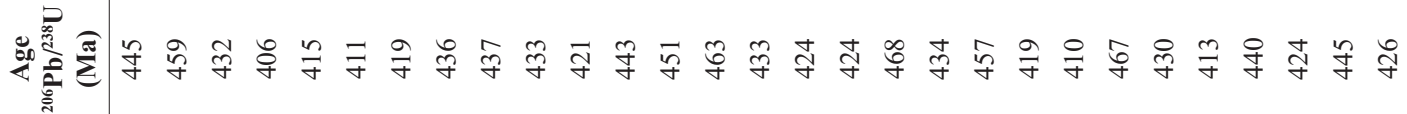

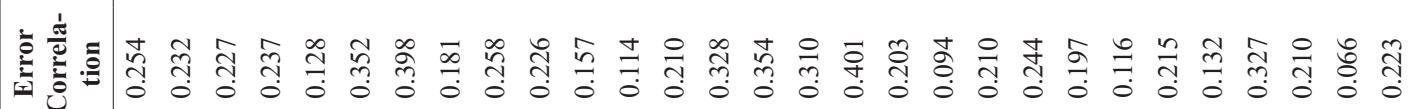

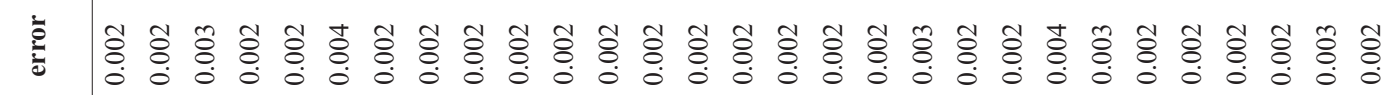

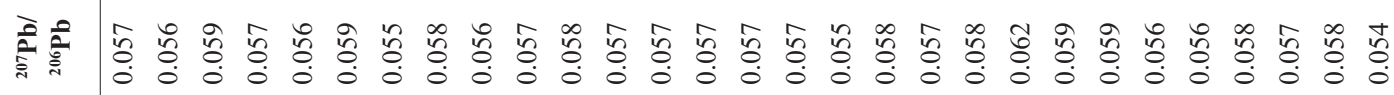

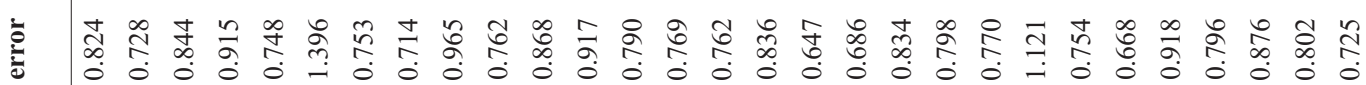

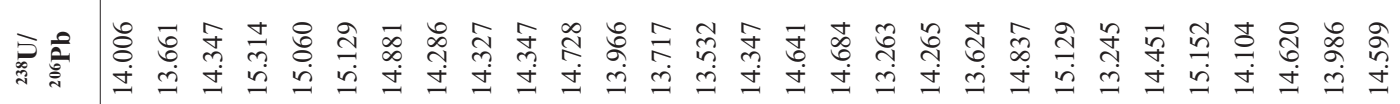

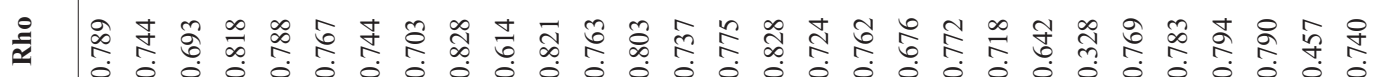

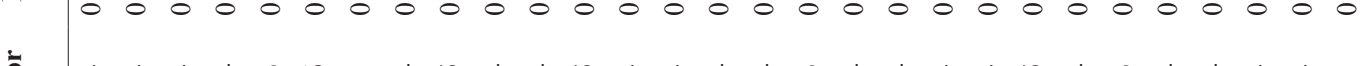

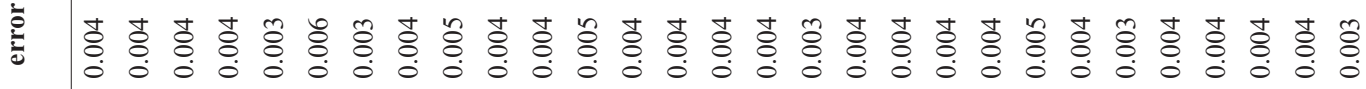

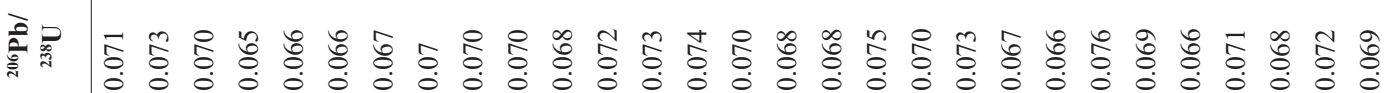
๘)

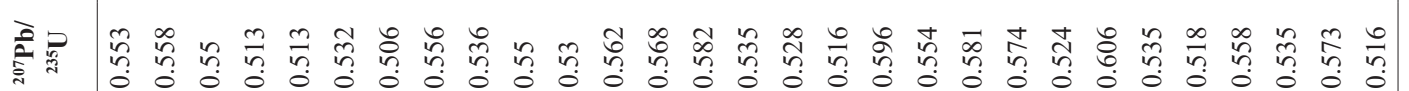

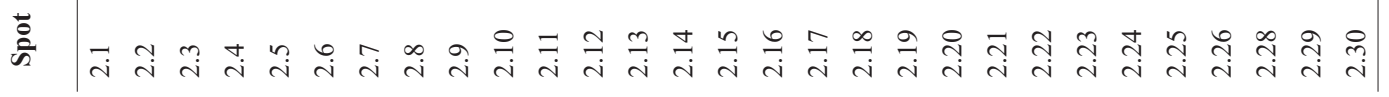


(Fig. 7): 1) Prismatic, 130-150 $\mu \mathrm{m}$ zircons with aspect ratios of approximately $2: 1 ; 2$ ) Subrounded, $120-175 \mu \mathrm{m}$ grains with aspect ratios near $2: 1 ; 3$ ) Rounded, 70-130 $\mu \mathrm{m}$ zircons with aspect ratios of 1:1.

From the total analyzed zircons, eight analyses were discarded based on their discordant ages and for having high common $\mathrm{Pb}$. Sixty-two zircons yielded concordant ages defining three main populations (Fig. 7 and 8): a P1 population (11\% of the samples) with ages that range from 656 to $496 \mathrm{Ma}$; a P2 population ( $63 \%$ of the pattern) with ages between 1,264 and $874 \mathrm{Ma}$; and a P3 population $(19.5 \%$ of samples) between 1,510 and 1,299 Ma. There are single analyses of 1,891, 2,056, 2,127 and 2,556 Ma (Fig. 8A). The main population (P2) corresponds to Mesoproterozoic ages where there can be recognized three morphological types of zircons: prismatic, subrounded and rounded. The most representative types of zircons are rounded and correspond to class
4-5 of Gärtner et al. (2013). Meanwhile, prismatic zircons are scarce and can be attributed to classes P1 and P2 of Pupin (1980).

Maximum deposition age was determined considering the methods in Dickinson and Gehrels, (2009) and the Unmix routine in ISOPLOT/Ex (Ludwig, 2003). This method also calculates the age and uncertainties for each component. The group of three youngest zircons was taken into consideration to estimate the maximum deposition age, resulting on a mean age of $501 \pm 14 \mathrm{Ma}(\mathrm{MSWD}=0.19)$, while the youngest Unmix age is $50415 \mathrm{Ma}$. This last age was calculated by ISOPLOT (Ludwig, 2003) from the youngest group of zircons from P1 population. Considering that both ages are similar and within the error of the youngest single zircon grain $(496 \pm 21 \mathrm{Ma})$, we consider the mean of the three youngest zircons as the maximum deposition age (Fig. 8B).

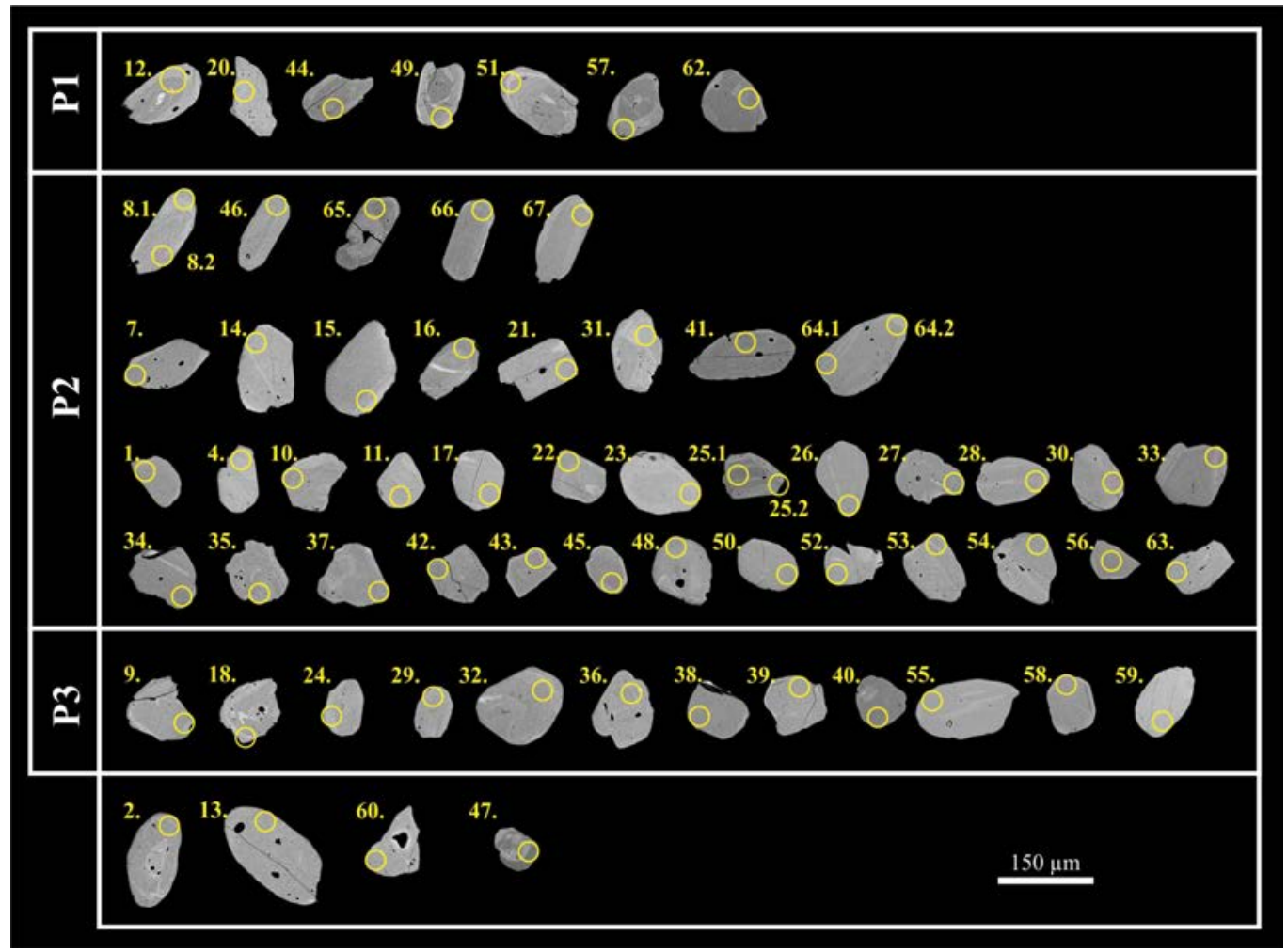

FIG. 7. Backscattered images of the detrital zircons analyzed by LA-Q-ICP-MS of the metasedimentary rock from Serra-Varela et al. (2016). Spot number is shown for each grain. Based on age distributions different populations were identified: P1 population ( 656 to $496 \mathrm{Ma}$ ); P2 population (1,264 to $874 \mathrm{Ma}$ ); and P3 population (1,510 to 1,299 Ma). Single grains display ages of 1,891, 2,056, 2,127 and 2,556 Ma. Spot size of $30 \mu \mathrm{m}$. 


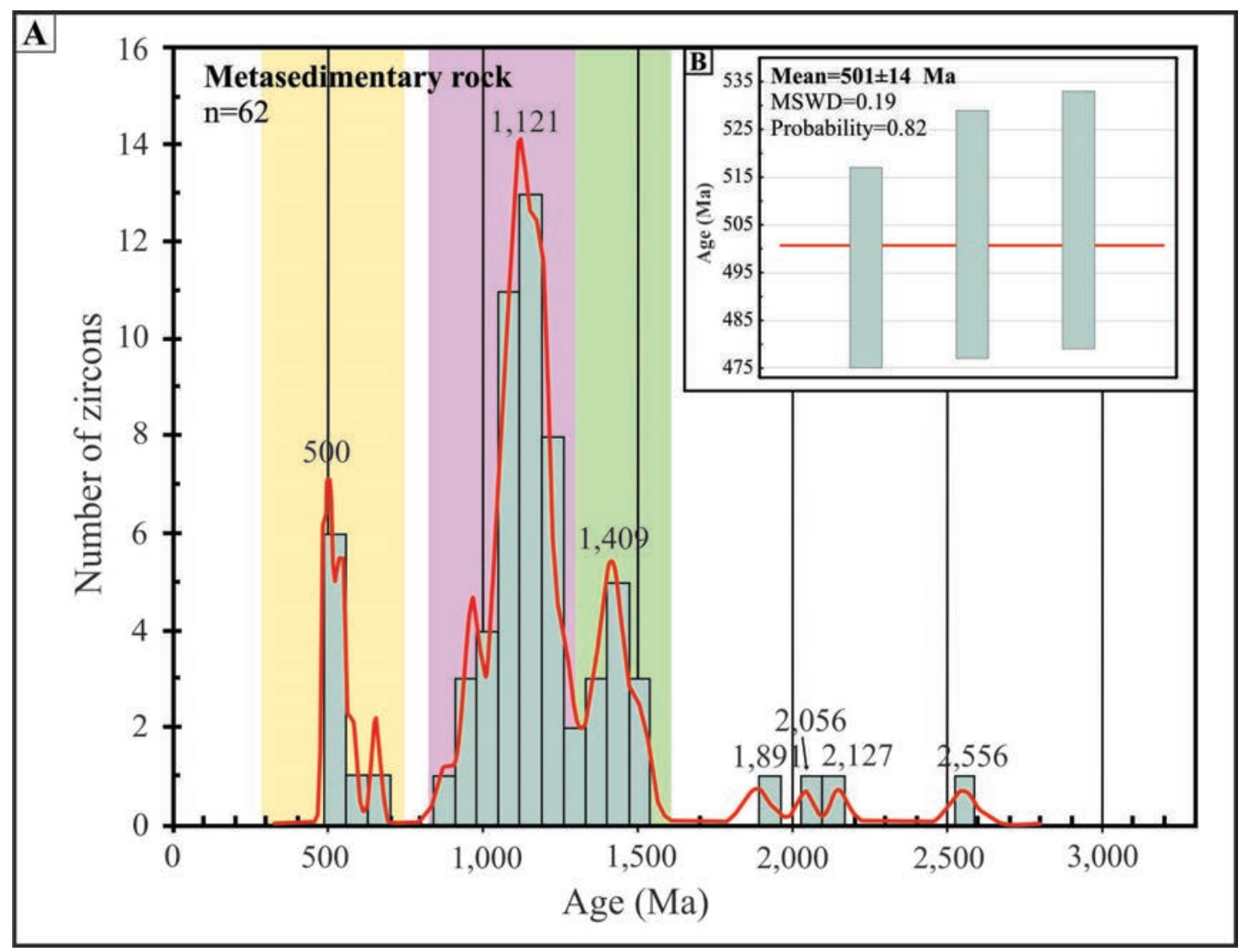

FIG. 8. Ages of the analysed detrital zircons, the uncertainties are at $2 \sigma$ level. A. Relative probability plot (red curve) and frequency histograms (light green bars) of the detrital zircon ages. Colored bars represent the different population distinguished. P1 (yellow), P2 (violet) and P3 (green). B. Mean age of the three youngest zircons from the analysed detrital zircon analysis.

\subsection{Anatectic granite crystallization age}

Zircons from the anatectic granite are euhedral, prismatic and transparent. Their lengths range from 110 to $340 \mu \mathrm{m}$. Zircons were classified following the typological classification of Pupin (1980). They fall into the S4, S5, S9 and S10 category. In backscattered images, most crystals show oscillatory zoning (Fig. 9). Zircons have Th/U ratios ranging from 0.05 to 0.5 . Normally, high $\mathrm{Th} / \mathrm{U}$ ratios (greater than 0.1 ) are attributed to magmatic zircons but they can also be recognized in recrystallized zircons during anatexis or grown during high temperature metamorphism (Harley and Nandakumar, 2014; Schaltegger et al., 1999; Vavra et al., 1999). Instead, low $\mathrm{Th} / \mathrm{U}$ ratios (less than 0.1 ) can be associated with metamorphic overgrowth (Rubatto et al., 2001) or a late-stage mineral-fluid interaction (Carson et al., 2002; Harley and Nandakumar, 2014; Vavra et al., 1999).

Thirty analyses were carried out in thirty different zircons. Twenty-nine concordant ages were obtained. Zircons can be divided into 3 groups based on their ages (Fig. 10A). The main group is composed of nineteen analyses and we considered that it defines the crystallization age of the granite. This cluster yielded a mean age of $430.3 \pm 5.2(\mathrm{MSWD}=0.54)$ and defines a Concordia age of $=434.1 \pm 4.5 \mathrm{Ma}$ (MSWD=4.8). Another group is composed by six zircons whose mean age is $461 \pm 10 \mathrm{Ma}$. (MSWD $=0.27$ ). These zircons show inherited cores that were partly included in the analyzed spot giving an aged mixedage. The remaining four zircons gave a mean age of $416.4 \pm 9.7 \mathrm{Ma}(\mathrm{MSWD}=0.37$ ) (Fig. 10A and B). This could be a younger age caused by rejuvenation due to the Lower Devonian granitoids emplacement. 


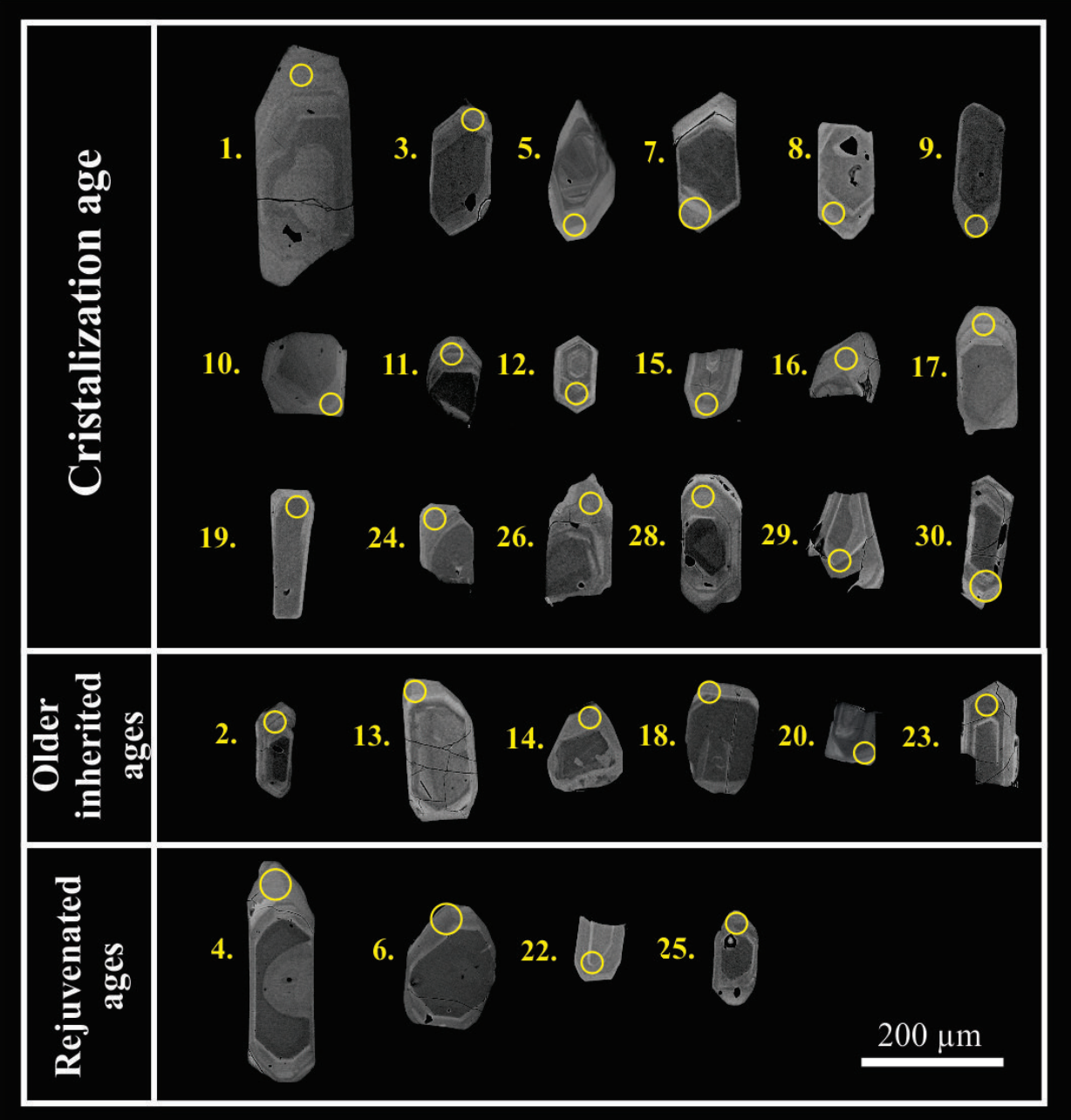

FIG. 9. Backscattered images of the zircons from the anatectic granite analyzed by LA-Q-ICP-MS separated in three age groups: crystallization ages, inherited ages and rejuvenated. Spot number is shown for each grain. Spot size of $30 \mu \mathrm{m}$.

\section{Discussion}

\subsection{Migmatization and deformation ages}

As it was mentioned before, leucosomes of the migmatic rocks are parallel and also cut the regional tectonic foliation of gneisses and schists (interpreted to be an $\mathrm{S}_{2}$ ). On the other hand, the Devonian granites cut tectonic foliations and migmatitic rocks. These field relations constrain the deformation event between the maximum depositional age of the sedimentary protolith (Cambrian Epoch 3, ca. $501 \mathrm{Ma}$ ) and the crystallization of the oldest Devonian granites (Emsian, ca. $400 \mathrm{Ma}$ ) (Fig.11).
The dated anatectic granite has the same field relations and similar geochemical features as the leucosomes of diatexite migmatites. For this reason, the $\mathrm{U}-\mathrm{Pb}$ zircon crystallization age obtained for this anatectic granite can be considered as the age of the main migmatization event. The emplacement of the anatectic granite took place during LlandoveryWenlock, at approximately 430-434 Ma. This age is a good constraint for the metamorphic peak and for the end of the regional $\left(\mathrm{D}_{2}\right)$ deformation event (Fig. 11).

One previous age obtained by Lucassen et al. (2004) for a migmatite in this area (Rb-Sr whole rock age) yielded $368 \pm 9$ Ma. This age is younger 


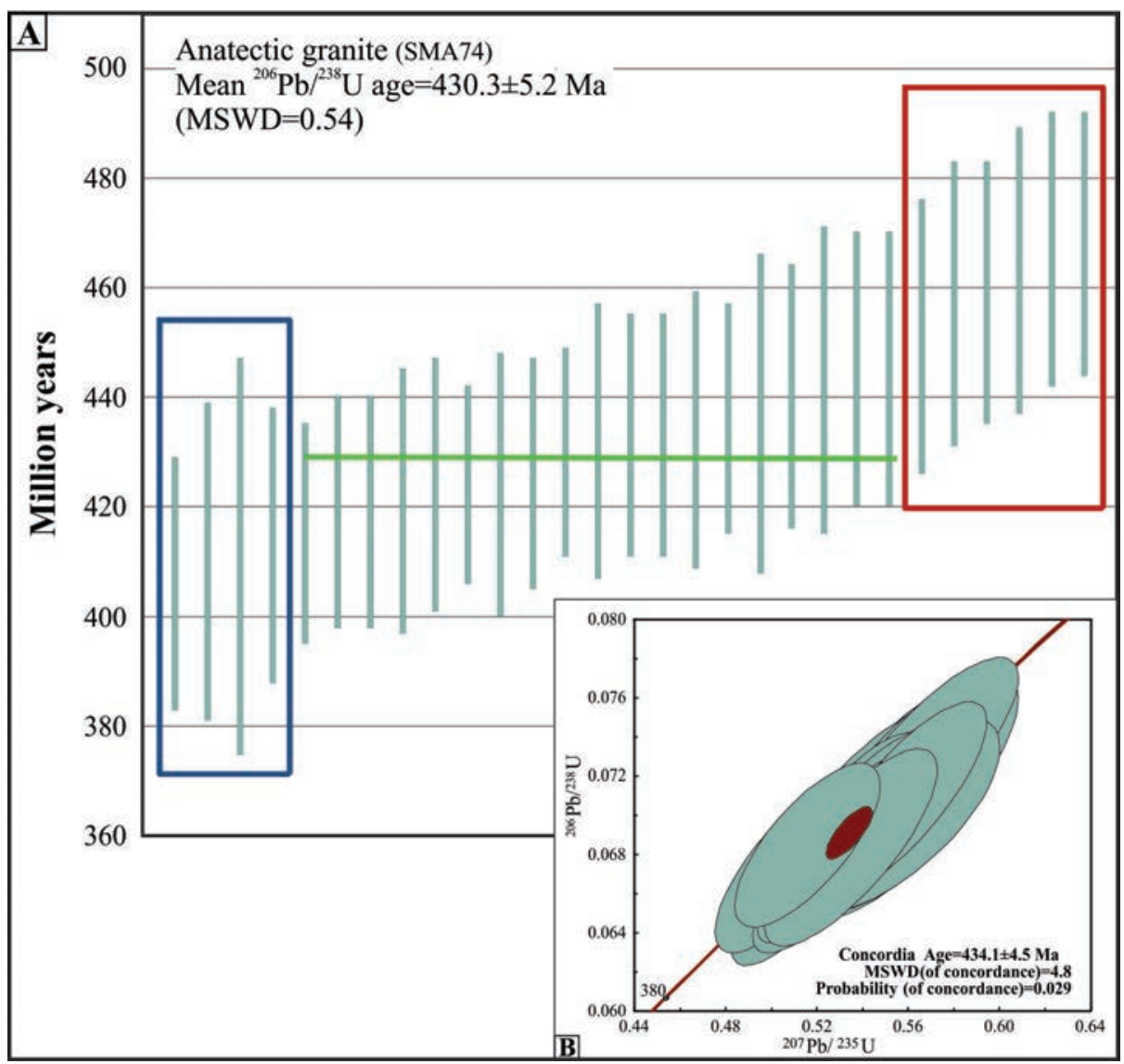

FIG. 10. Crystallization age obtained for the anatectic granite. A. Mean age of nineteen concordant zircons. The blue square shows the youngest group of ages interpreted as rejuvenation ages, while the red square comprises the oldest group considered as inherited ages. The green line represents the mean of the crystallization ages; $\mathbf{B}$. Concordia age calculated for the crystallization ages. Ellipses depict $2 \sigma$ errors.

than the Devonian granites and should be considered as a resetting age of the $\mathrm{Rb}-\mathrm{Sr}$ system. In addition, in other localities of the North Patagonian Andes, metamorphic ages between $c a .391$ and $305 \mathrm{Ma}$ were reported by several authors (Martínez et al., 2012; Pankhurst et al., 2006; Urraza et al., 2011; Willner et al., 2004). These tectono-metamorphic events, developed between Middle Devonian and late Carboniferous (Pennsylvanian), probably related with the active subduction of the Gondwanan orogeny (Heredia et al., 2016, 2018), could be the cause of this age resetting.

\subsection{Origin and age of the sedimentary protolith}

Based on geochemical and petrographic features, the protolith of San Martín de los Andes metamorphic rocks is defined as a sequence of greywackes with minor pelites that underwent high-grade metamorphic conditions. Samples of schists with marked schistosity and a metamorphic assemblage with abundant sillimanite are accountable of an Al-rich protolith that corresponds to pelites (Bucher and Grapes, 2011). Moreover, gneisses with cordierite and minor sillimanite as well as gneisses with amphibole, are considered as products of metamorphism of greywackes in amphibolite facies (Bucher and Grapes, 2011; Sawyer, 1987).

In order to characterize the tectonic setting and the protolith, provenence we used immobile trace elements and REE ratios. $\mathrm{Th} / \mathrm{Sc}$ ratios of the metasedimentary rocks, metatexites and schlieren diatexites range between 0.51 and 0.79 (Fig. 12). These values point to diferenciated igneous rocks 


\begin{tabular}{|c|c|c|c|c|c|c|c|}
\hline & Structure & Metamorphism & Lithology & $\begin{array}{c}\text { Geological } \\
\text { time }\end{array}$ & \begin{tabular}{|c|} 
Geodynamic \\
setting
\end{tabular} & \multicolumn{2}{|c|}{ Orogenic cycle } \\
\hline & \multirow{2}{*}{$\begin{array}{l}\text { NW-SE trending folds } \\
\text { affecting metamorphic } \\
\text { rocks. Shear zones and } \\
\text { foliation affecting Devonian } \\
\text { granitoids }\end{array}$} & \multirow{2}{*}{$\begin{array}{l}\text { M2: low grade } \\
\text { metamorphism }\end{array}$} & \multirow{2}{*}{$\begin{array}{l}\text { Without record } \\
\text { in the area }\end{array}$} & $\begin{array}{c}\text { Late } \\
\text { Carboniferous- } \\
\text { early Permian }\end{array}$ & $\begin{array}{l}\text { Collisional } \\
\text { stage }\end{array}$ & \multirow{2}{*}{ 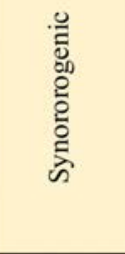 } & \multirow{3}{*}{ 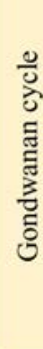 } \\
\hline & & & & \begin{tabular}{|c|} 
Late Devonian \\
early Carbonif \\
370-350 Ma.
\end{tabular} & \multirow{2}{*}{$\begin{array}{l}\text { Subduction } \\
\text { and } \\
\text { Magmatic arc }\end{array}$} & & \\
\hline & Magmatic foliation & & $\begin{array}{c}\text { Granodiorites } \\
\text { tonalites and } \\
\text { gabbros }\end{array}$ & \begin{tabular}{|r|} 
Early Devonian \\
$370-400 \mathrm{Ma}$.
\end{tabular} & & $\begin{array}{c}\text { Pre- } \\
\text { orogenic }\end{array}$ & \\
\hline D3 & $\begin{array}{l}\text { Crenulation affecting } \mathrm{S}_{2} ; \\
\mathrm{S}_{3} \text { spaced schistosity }\end{array}$ & Migmatization & $\begin{array}{c}\text { Anatectic granites } \\
\text { metatexites, } \\
\text { diatexites }\end{array}$ & $\begin{array}{c}\text { Silurian } \\
\text { (Wenlock) } \\
\text { ca. } 430 \mathrm{Ma} .\end{array}$ & \multirow{2}{*}{$\begin{array}{l}\text { Collisional } \\
\text { stage }\end{array}$} & \multirow{2}{*}{ 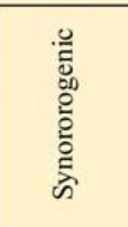 } & \multirow{3}{*}{ 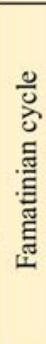 } \\
\hline \multirow[t]{2}{*}{$\begin{array}{l}\text { D2 } \\
\text { D1 }\end{array}$} & $\begin{array}{l}S_{2} \text { regional foliation } \\
S_{1} \text { relict foliation }\end{array}$ & $\begin{array}{l}\text { M1: regional } \\
\text { metamorphism. }\end{array}$ & $\begin{array}{l}\text { Schists and } \\
\text { gneisses }\end{array}$ & $\begin{array}{l}\text { Ordovician?- } \\
\text { early Silurian }\end{array}$ & & & \\
\hline & $\begin{array}{c}\text { Stratification of the } \\
\text { sedimentary rocks }\left(\mathrm{S}_{0}\right) \text {. }\end{array}$ & & $\begin{array}{c}\text { Alternate layers } \\
\text { of pelites and } \\
\text { greywackes }\end{array}$ & $\begin{array}{l}\text { Post-Cambrian } \\
\text { ca. } 501 \mathrm{Ma} .\end{array}$ & $\begin{array}{l}\text { Passive } \\
\text { margin? }\end{array}$ & $\begin{array}{l}\text { Pre- } \\
\text { orogenic }\end{array}$ & \\
\hline
\end{tabular}

FIG.11. Resume chart showing the geological Palaeozoic evolution of the San Martín de los Andes area considering structure, metamorphism and lithology. Based on Heredia et al. (2016).

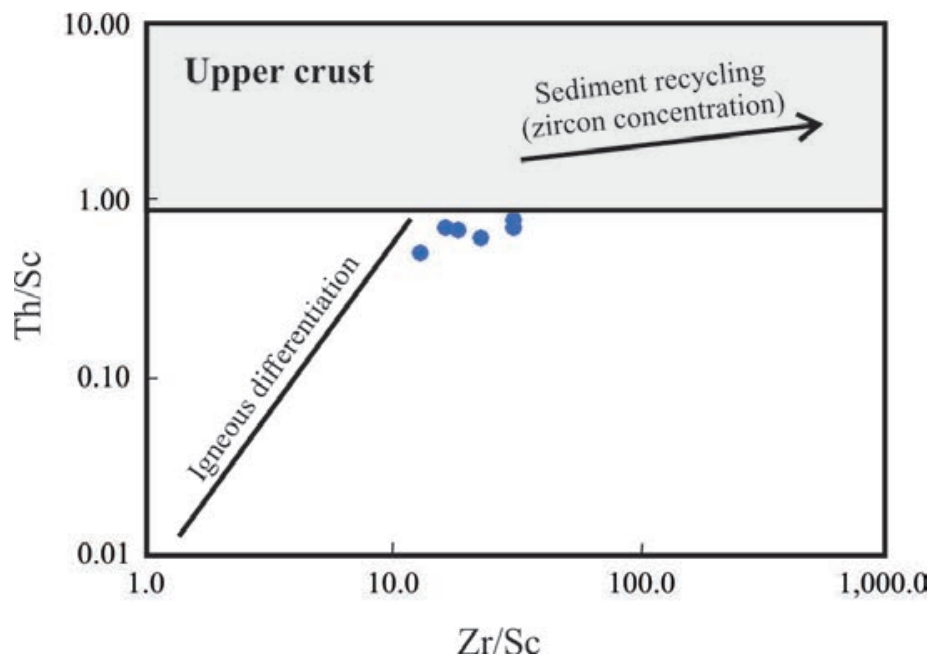

FIG. 12. Th/Sc-Zr/Sc ratio diagram after McLennan et al. (1993). This diagram shows the composition of the sources and the extent of recycling or concentration of $\mathrm{Zr}$ in the sedimentary protolith, associated with the abundance of heavy minerals, particularly zircon.

as posible source for sedimentary rocks (Bahlburg, 1998; McLennan et al., 1993). Contents of Zr, Th and Sc, and a small negative Eu anomaly, indicate that these greywackes and pelites could have derived from a magmatic arc with igneous rocks similar in composition to an andesite (Bhatia and Crook, 1986).
Based on detrital zircon U-Pb age determinations, the maximum depositional age of the metamorphic rocks protolith in San Martín de los Andes is constrained at $501 \pm 14 \mathrm{Ma}$. This suggests that sedimentation occurred sometime between Cambrian Epoch 3 and probably the Late Ordovician; considering 
that the regional deformation responsible for the $\mathrm{S}_{2}$ foliation must be pre-upper Llandovery (migmatization age is $c a .434 \mathrm{Ma}$ ) and the first phase must be older than this (Fig. 11). On the other hand, Hervé et al. (2016) reported a maximum depositional age for a sample of a metasedimentary rock in San Martín de los Andes of $c a .420 \mathrm{Ma}$. This age does not fit in the above interpretation, since it is younger than the age of the migmatization event presented in this contribution. However, we must recall that the two youngest peaks from Hervé et al. (2016) sample are $420 \mathrm{Ma}$ and $449 \mathrm{Ma}$ and roughly coincide with our obtained ages for the anatectic granite. For this reason, we consider that these zircons may not be detrital and might come from some small migmatitic veins potentially present in the sample analysed by these authors. Another reason could be that these ages might have been rejuvenated during the emplacement of the Devonian granites.

The detrital zircon pattern studied in this contribution shows that the dominant input for this sediment was derived from Mesoproterozoic rocks. Two Mesoproterozoic inputs were identified: one corresponds to early Mesoproterozoic ages (main probability peak $c a \cdot 1,416 \mathrm{Ma}$ ) and the other to late Mesoproterozoic ages (main probability peak $c a$. 1,110 Ma). The late Mesoproterozoic group is the most important population (63\% of the analyzed zircons). In contrast, ages close to maximum depositional age are subordinated on the pattern ( $11 \%$ of the analyzed zircons).

\subsection{Metamorphic evolution and melting conditions}

The described protolith underwent high-grade metamorphic conditions resulting in schists and gneisses. Peak P-T conditions calculated with pseudosections for San Martín de los Andes migmatites are within upper amphibolite facies, in a low pressurehigh temperature (LP-HT) type of metamorphism (between $660-740{ }^{\circ} \mathrm{C}$ and pressures below $0.45 \mathrm{GPa}$, according to Serra-Varela et al., 2017).

This range of temperatures and the paragenesis found in different rocks suggest that the first melting reaction was the breakdown of muscovite: $\mathrm{Ms}+\mathrm{Pl}+\mathrm{Qtz}=\mathrm{Sil}+\mathrm{melt}$ (Icenhower and London, 1995). Moreover, trondhjemitic leucosomes are accountable for $\mathrm{H}_{2} \mathrm{O}$-flux melting of a metapelitic source rock where melting reaction involving muscovite plays an important role (Patiño Douce and Harris, 1998).
The presence of water-involved reaction is also consistent with the low $\mathrm{Rb} / \mathrm{Sr}$ ratio $(<1.6$; Harris and Inger, 1992) and low contents of $\mathrm{Zr}(<50 \mathrm{ppm})$ where $\mathrm{H}_{2} \mathrm{O}$-fluxed melting tends to separate biotites with zircons in the residue and $\mathrm{Zr}$ is not incorporated in melt (Otamendi and Patiño Douce, 2001; Patiño Douce and Harris, 1998).

In addition, petrography of schists indicates that dehydration melting of biotite was probably a secondary melting reaction where $\mathrm{Bt}+\mathrm{Pl}+\mathrm{Sil}+\mathrm{Qtz}=\mathrm{Crd}+\mathrm{Kfs}+$ melt. This reaction is also inferred by the high contents of $\mathrm{CaO}$ and $\mathrm{FeO}+\mathrm{MgO}$ of the anatectic granite. Melting of a biotite-plagioclase gneiss with influx of water can generate granodioritic melts with high $\mathrm{CaO}$ and $\mathrm{FeO}+\mathrm{MgO}$ content (Otamendi and Patiño Douce, 2001).

Finally, a late retrograde hydration stage is recognized by the presence of symplectitic textures between micas (muscovite and biotite) and quartz (Brown, 2002; White et al., 2005). This re-hydration stage is also suggested by post-kinematic muscovite porphyroblasts, with rims of Ms+Qtz symplectites, which overprint the previous metamorphic fabric of the mesosome and the metasedimentary rocks near diatexites.

\subsection{Geotectonic setting and correlations}

About $400 \mathrm{~km}$ east of the studied area, in the eastern North Patagonian Massif, metasedimentary rocks from El Jaguelito and Nahuel Niyeu Formations and Mina Gonzalito Complex (Caminos, 1983; Giacosa, 1987; Ramos, 1975) have maximum depositional ages between 535 and $510 \mathrm{Ma}$ (Greco et al., 2017; Naipauer et al., 2010; Pankhurst et al., 2006; Rapalini et al., 2013). Greco et al. (2015) constrained the depositional age of the Nahuel Niyeu Formation at around $513 \mathrm{Ma}$. These ages are remarkably similar to the one obtained in this contribution for the San Martín de los Andes metamorphic basement. Moreover, arc-related igneous rocks were dated around 515-490 (Cambrian-Ordovician) and between ca. 472-454 Ma (Ordovician) in the North Patagonian and Deseado massifs (Greco et al., 2015; Pankhurst et al., 2006, 2014; Rapalini et al., 2013; Varela et al., 2011).

In terms of metamorphism and deformation, the Mina Gonzalito Complex shows N-S to NNW-SSE structures (mainly folds with some shear zones), which are cut by upper Lower Ordovician granitoids ( $c a$. 472 Ma; González et al., 2008). The thermal peak 
would have occurred before the $472 \mathrm{Ma}$ (in Early Ordovician or Cambrian times), reaching the upper amphibolite facies in intermediate temperature and pressure (IT-IP) metamorphic conditions (González et al., 2008; Greco et al., 2014; Pankhurst et al., 2006). All this indicates that both the metamorphism and the deformation are older than those described in the San Martín de los Andes area. These CambrianOrdovician magmatic and tectono-metamorphic events have recently been related to the Ross orogenic cycle by Ramos and Naipauer (2014) and Heredia et al. (2016).

The upper Lower Ordovician plutonic rocks of the eastern North Patagonian Massif were also deformed in metamorphic conditions by some subsequent event, prior to the deposition of the rocks included in the Sierra Grande Formation, of late Silurian-early Devonian age (Wenlock in the basal part, according to fossils collected by Müller, 1965), which unconformably cover the older rocks. This tectono-metamorphic event is similar in age to the one described in our study area (climax in around $434 \mathrm{Ma}$, Llandovery-Wenlock limit) and implies that the pre-Devonian deformation finished before the end of the Wenlock ( $c a .427 .5 \mathrm{Ma}$ ). Heredia et al. (2016) correlated this event to the Famatinian orogenic cycle of Patagonia.

The detrital zircon patterns for the basement of eastern North Patagonian Massif show the youngest peak close to the maximum sedimentation age of the basement units, at approximately $515 \mathrm{Ma}$ (Greco et al., 2015; Pankhurst et al., 2006). This peak reveals the presence of the active magmatic arc of Cambrian and Early Ordovician age. The detrital zircons also indicate older provenances for these units with peaks at $c a$. 550-650 (Cambrian-late Neoproterozoic) and $1,000-1,200 \mathrm{Ma}$ (late Mesoproterozoic), as well as isolated ages at ca. 2,200 Ma (Greco et al., 2017; Naipauer et al., 2010; Pankhurst et al., 2006, 2014; Rapalini et al., 2013).

On the other hand, detrital zircon analysis of metasedimentary rocks in San Martín de los Andes area exhibit a different pattern. A well-defined peak of ages is given in the early Mesoproterozoic (ca. 1,409 Ma), which is missing in eastern North Patagonian basement rocks. In addition, the zircon pattern studied in this contribution has few young zircons from the Cambrian-Ordovician active arcs (Fig. 13). These differences suggest a dissimilar basin with different source rocks for these protoliths.
Recently, Heredia et al. $(2016,2018)$ proposed a new tectonic evolution for the Palaeozoic of Northern Patagonia, based in the accretion to the southwestern margin of Gondwana of different continental fragments. For these authors, during the Ordovician-Silurian, a peri-gondwanic continental block, Western Patagonia, was accreted to Gondwana, producing the Patagonian Famatinian orogeny. This accretion was favored by an Ordovician subduction developed beneath Gondwana. In this context, the eastern North Patagonian Massif would be part of the Gondwana margin and the North Patagonian Andes would be part of the eastern margin of Western Patagonia. This tectonic setting could explain the different patterns of detrital zircons found in the rocks of the North Patagonian Massif and the studied area and the differences between deformational ages.

\section{Conclusions}

Based on the petrological, structural, geochemical and geochronological data presented in this contribution, the following conclusions can be drawn:

- The protolith of San Martín de los Andes high-grade metamorphic rocks, including the migmatites, was a sequence of greywackes with minor pelites.

- Detrital zircon dating constrains the maximum depositional age for San Martín de los Andes metasedimentary rocks in 501 \pm 14 Ma (Series 3 Cambrian). The source rock ages are mainly Mesoproterozoic, although older and younger ages are also found.

- The early Palaeozoic basins located in eastern Patagonia (North Patagonian and Deseado massifs) and in the North Patagonian Andes (study area) were active during a similar period of time but in different tectonic settings.

- Migmatites are well represented within the highgrade metamorphic rocks from the study area. Two metamorphic melting reactions were recognized based on geochemical and petrological data. The most important one being the breakdown of muscovite, followed by the breakdown of biotite. Both reactions would have occurred under the influx of water.

- The high-grade metamorphic rocks at San Martín de los Andes area show a pervasive regional foliation (schistosity) that contains the main metamorphic assemblage and we consider this foliation to be $\mathrm{S}_{2}$. The identification of the $\mathrm{S}_{1}$ is restricted to 

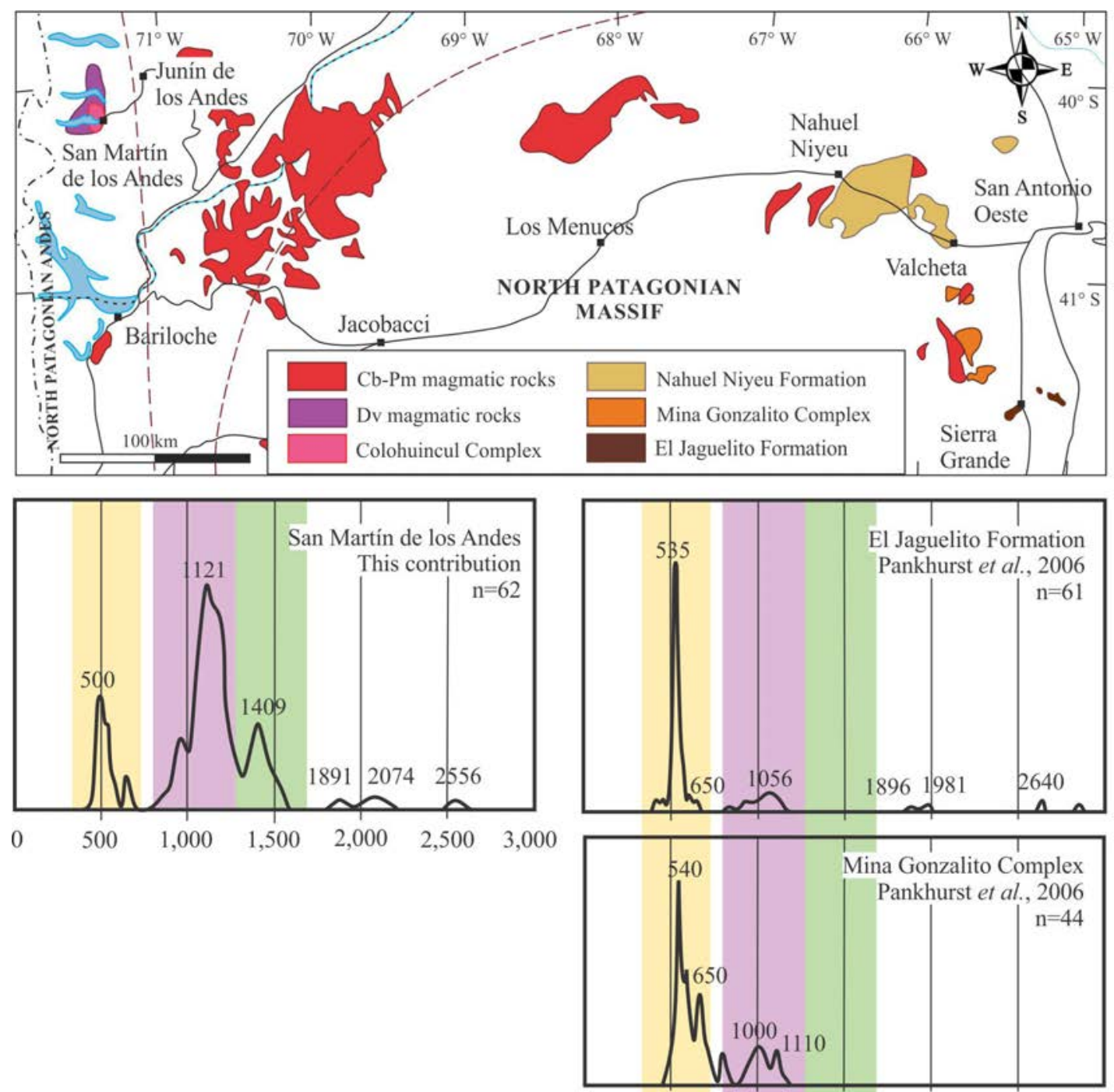

FIG. 13. Regional geological sketch map showing the different basement units for the North Patagonian Andes and the North Patagonian Massif (modified from Pankhurst et al., 2006). Relative probability plots for El Jaguelito Formation, Mina Gonzalito Complex and Nahuel Niyeu Formation (from Pankhurst et al., 2006, 2014) are shown in order to compare them with the San Martín de los Andes basement detrital zircon pattern. Colored bars represent the different population distinguished for San Martín de los Andes samples. P1 (yellow), P2 (violet) and P3 (green).

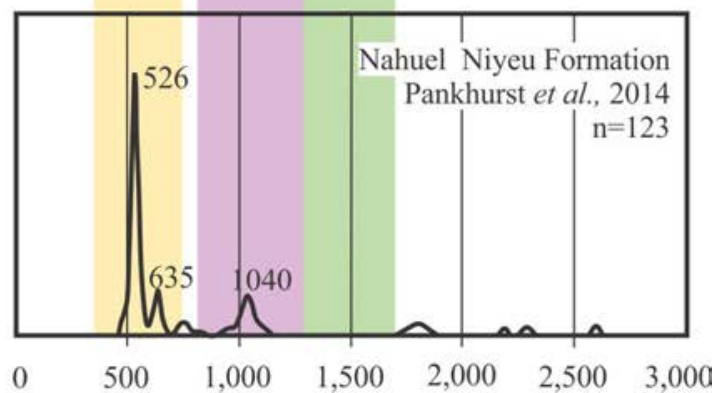

microlithons in thin sections but the intensity of deformation and metamorphism during the second phase overprinted previous microstructures. The last deformation event produced the crenulation of the $\mathrm{S}_{2}$, with local development of a very incipient

crenulation cleavage $\left(\mathrm{S}_{3}\right)$, mainly developed close to the hinge of gentle asymmetrical folds.

- The migmatization and anatectic processes of the metasedimentary rocks took place during the early Silurian at 430.3 $\pm 5.2-434.1 \pm 4.5 \mathrm{Ma}$ 
(Llandovery-Wenlock) and its relationship with the deformation indicates that its age is syn- to post- $\mathrm{D}_{2}\left(\mathrm{~S}_{2}\right)$. This suggests that the study area was located in the internal zones of the Patagonian Famatinian orogen (in the sense of Heredia et al. 2016), which would have been deformed before the end of the Wenlock ( $c a .427 \mathrm{Ma}$ ), since the post-orogenic Sierra Grande Formation is late Silurian to early Devonian in age.

- Brittle-ductile structures with a NNW-SSE trend and developed under low-grade metamorphic conditions, affected the high-grade Famatinian rocks and Devonian granitoids. This tectono-metamorphic event can be associated to the Gondwanan orogeny. The main structures interpreted as Gondwanan are centimetric to hectometric shear bands, the thickest of which shows SW dip and NE tectonic transport direction.

- Brittle, N-S trending structures, related to an Andean thrust and fold belt, slightly deformed the Palaeozoic basement rocks in Cenozoic times. The geometry (dip and trend) of the Andean thrusts seems to be conditioned by the orientation of the previous Gondwanan shear bands.

\section{Acknowledgements}

This work is part of the S. Serra-Varela Ph.D. Thesis and has been supported by projects PIP-CONICET 112201101-00324 of Argentina and TORANDES (CGL201238396-C03) of the Spanish I+D+i Plan with FEDER Funds of the European Union. The authors would like to thank National's Park Office, especially forest ranger G. D'Oliveira (Lolog Section) for his assistance. We also like to acknowledge Dr. S. González (IIPG) for his field assistance and B. Boltshauser (IIPG) for the suggestions made on this manuscript. We thank W. Vivallo and C. Cingolani for their helpful and valuable comments which improve this manuscript.

\section{References}

Bahlburg, H. 1998. The geochemistry and provenance of Ordovician turbidites in the Argentine Puna. Geological Society, Special Publications 142 (1): 127-142. London

Barker, F. 1979. Trondhjemite: definition, environment and hypotheses of origin. In Trondhjemites, dacites and related rocks. Elsevier Ltd.: 1-12. Amsterdam.

Bhatia, M.R.; Crook, K.A.W. 1986. Trace element characteristics of greywackes and tectonic setting discrimination of sedimentary basins. Contributions to Mineralogy and Petrology 92: 181-193.

Brown, M. 2002. Retrograde processes in migmatites and granulites revisited. Journal of Metamorphic Geology 20 (1): 25-40.

Bucher, K.; Grapes, R. 2011. Petrogenesis of Metamorphic Rocks. Springer Berlin Heidelberg: 428 p. Berlin.

Caminos, R. 1983. Descripción geológica de las Hojas 39g, Cerro Tapiluke y 39h, Chipauquil, Provincia de Río Negro. Servicio Geológico y Minero Nacional: 41 p. Buenos Aires.

Carson, C.J.; Ague, J.J.; Grove, M.; Coath, C.D.; Harrison, T.M. 2002. U-Pb isotopic behaviour of zircon during upper-amphibolite facies fluid infiltration in the Napier Complex, East Antarctica. Earth and Planetary Science Letters 199 (3-4): 287-310.

Cingolani, C.A.; Zanettini, J.C.M.; Leanza, H.A. 2011. El basamento ígneo y metamórfico. In Relatorio Congreso Geológico, No. 18 (Leanza, H.A.; Arregui, C.; Carbone, O.; Danieli, J.; Vallés, J.; editors). Geología y Recursos Naturales de la Provincia de Neuquén: 37-47. Neuquén.

Cucchi, R.; Leanza, H.A. 2006. Hoja Geológica 3972-IV Junín de los Andes, provincia del Neuquén. Servicio Geológico y Minero Nacional (SEGEMAR): 102 p.

Dalla Salda, L.; Cingolani, C.A.; Varela, R. 1991. El basamento pre-andino ígneo metamórfico de San Martín de los Andes, Neuquén. Revista de la Asociacion Geológica Argentina 46 (3-4): 223-234.

Dickinson, W.R.; Gehrels, G.E. 2009. Use of U-Pb ages of detrital zircons to infer maximum depositional ages of strata: A test against a Colorado Plateau Mesozoic database. Earth and Planetary Science Letters 288 (1-2): 115-125.

Escosteguy, L.; Franchi, M. 2010. Estratigrafía de la región de Chapelco, provincia del Neuquén. Revista de la Asociación Geológica Argentina 66 (3): 418-429.

Folguera, A.; Vera, E.R.; Spagnuolo, M.; Orts, D.; Sagripanti, L.; Mariot, M.; Ramos, M.; Bottesi, G. 2011. Los Andes Neuquinos. In Relatorio Congreso Geológico, No. 18 (Leanza, H.A.; Arregui, C.; Carbone, O.; Danieli, J.; Vallés J.; editors). Geología y Recursos Naturales de la Provincia de Neuquén: 349-354. Neuquén.

García-Sansegundo, J.; Farias, P.; Gallastegui, G.; Giacosa, R.E.; Heredia, N. 2009. Structure and metamorphism of the Gondwanan basement in the Bariloche region (North Patagonian Argentine Andes). International Journal of Earth Sciences 98 (7): 1599-1608.

Gärtner, A.; Linnemann, U.; Sagawe, A.; Hofmann, M.; Ullrich, B.; Kleber, A. 2013. Morphology of zircon crystal grains in sediments-characteristics, 
classifications, definitions. Journal of Central European Geology 59: 65-73.

Giacosa, R. 1987. Caracterización de un sector del basamento metamórfico-migmático en el extremo suroriental del Macizo Norpatagónico, Provincia de Río Negro, Argentina. In Congreso Geológico Argentino, No. 10: 51-54. San Miguel de Tucumán.

González, P.D.; Varela, R.; Sato, A.M.; Llambías, E.J. 2008. Dos fajas estructurales distintas en el Complejo Mina Gonzalito, Río Negro. In Congreso Geológico Argentino, No. 17: 847-848. San Salvador de Jujuy.

Greco, G.; González, S.; Sato, A.; González, P.; Llambías, E.J.; Basei, M. 2014. Nueva datación en circones detríticos para el Complejo Mina Gonzalito, provincia de Río Negro. In Congreso Geológico Argentino, No. 19: 847-848. Córdoba.

Greco, G.; González, P.D.; González, S.N.; Sato, A.M.; Basei, M.A.S.; Tassinari, C.C.G.; Sato, K.; Varela, R.; Llambías, E.J. 2015. Geology, structure and age of the Nahuel Niyeu Formation in the Aguada Cecilio area, North Patagonian Massif, Argentina. Journal of South American Earth Sciences 62: 12-32.

Greco, G.A.; González, S.; Sato, A.M.; González, P.D.; Basei, M.A.S.; Llambías, E.J.; Varela, R. 2017. The Nahuel Niyeu basin: A Cambrian forearc basin in the eastern North Patagonian Massif. Journal of South American Earth Sciences 79: 111-136.

Harley, S.L.; Nandakumar, V. 2014. Accessory Mineral Behaviour in Granulite Migmatites: a Case Study from the Kerala Khondalite Belt, India. Journal of Petrology 55 (10): 1965-2002.

Harris, N.B.W.; Inger, S. 1992. Trace element modelling of pelite-derived granites. Contributions to Mineralogy and Petrology 110 (1): 46-56.

Heredia, N.; García-Sansegundo, J.; Gallastegui, G.; Farias, P.; Giacosa, R.E.; Alonso, J.L.; Busquets, P.; Charrier, R.; Clariana, P.; Colombo, F.; Cuesta, A.; Gallastegui, J.; Giambiagi, L.; González-Menéndez, L.; Limarino, C.O.; Martín-González, F.; Pedreira, D.; Quintana, L.; Rodríguez-Fernández, L.R.; Rubio-Ordóñez, A.; Seggiaro, R.; Serra-Varela, S.; Spalletti, L.A.; Cardó, R.; Ramos, V.A. 2016. Evolución geodinámica de los Andes de Argentina, Chile y la Península Antártica durante el Neoproterozoico superior y el Paleozoico. Trabajos de Geología 36: 237-278.

Heredia, N.; García-Sansegundo, J.; Gallastegui, G.; Farias, P.; Giacosa, R.E.; Hongn, F.; Tubía, J.M.; Alonso, J.L.; Busquets, P.; Charrier, R.; Clariana, P.; Colombo, F.; Cuesta, A.; Gallastegui, J.; Giambiagi, L.; González-Menéndez, L.; Limarino, C.O.; Martín-
González, F.; Pedreira, D.; Quintana, L.; Rodríguez Fernández, L.R.; Rubio-Ordóñez, A.; Seggiaro, R.; Serra-Varela, S.; Spalletti, L.A.; Cardó, R.; Ramos, V. A. 2018. The Pre-Andean phases of construction of the Southern Andes basement in NeoproterozoicPaleozoic times. In The evolution of the Chilean and Argentinean Andes.(Folguera, A.; Contreras-Reyes, E.; Heredia, N.; Encinas, A.; Iannelli, S.; Oliveros, V.; Dávila, F.; Collo, G.; Giambiagi, L.; Maksymowicz, A.; Iglesia Llanos, M.P.; Turienzo, M.; Naipauer, M.; Orts, D.; Litvak, V.; Álvarez, O.; Arriagada, C.; editors). Springer-Verlag: 111-132.

Herron, M.M. 1988. Geochemical classification of terrigenous sands and shales from core or log data. Journal of Sedimentary Research 58 (5): 820-829.

Hervé, F.; Calderón, M.; Fanning, C.M.; Pankhurst, R.J.; Godoy, E. 2013. Provenance variations in the Late Paleozoic accretionary complex of central Chile as indicated by detrital zircons. Gondwana Research 23 (3): 1122-1135.

Hervé, F.; Calderón, M.; Fanning, C.M.; Pankhurst, R.J.; Fuentes, F.; Rapela, C.W.; Correa, J.; Quezada, P.; Marambio, C. 2016. Devonian magmatism in the accretionary complex of southern Chile. Journal of the Geological Society 173 (4): 587-602

Icenhower, J.; London, D. 1995. An experimental study of element partitioning among biotite, muscovite, and coexisting peraluminous silicic melt at $200 \mathrm{MPa}\left(\mathrm{H}_{2} \mathrm{O}\right)$. American Mineralogist 80 (11-12): 1229-1251.

Jackson, S.E.; Pearson, N.J.; Griffin, W.L.; Belousova, E.A. 2004. The application of laser ablation-inductively coupled plasma-mass spectrometry to in situ $\mathrm{U}-\mathrm{Pb}$ zircon geochronology. Chemical Geology 211 (1-2): 47-69.

Leanza, H.A.; Zanettini, J.C.M.; Rodríguez, M.F. 2011. Mapa geológico de la provincia de Neuquén escala 1:500.000. Servicio Geológico Minero Argentino. Buenos Aires.

Lucassen, F.; Trumbull, R.; Franz, G.; Creixell, C.; Vásquez, P.; Romer, R.L.; Figueroa, O. 2004. Distinguishing crustal recycling and juvenile additions at active continental margins: The Paleozoic to recent compositional evolution of the Chilean Pacific margin (36-41 ${ }^{\circ}$ S). Journal of South American Earth Sciences 17 (2): 103-119.

Ludwig, K.R. 2003. User's Manual for Isoplot 3.00-A Geochronological Toolkit for Microsoft Excel. Berkeley Geochronology Center Special Publication: 74 p.

Martínez, J.C.; Dristas, J.; Massonne, H.J. 2012. Palaeozoic accretion of the microcontinent Chilenia, North Patagonian Andes: high-pressure metamorphism and 
subsequent thermal relaxation. International Geology Review 54 (4): 472-490.

McLennan, S.M.; Hemming, S.; McDaniel, D.K.; Hanson, G.N. 1993. Geochemical approaches to sedimentation, provenance, and tectonics. Geological Society of America, Special Paper 284: 21-40.

Müller, H. 1965. Zur Altersfrage der Eisenerzlagerstätte Sierra Grande/Río Negro in Nordpatagonien Aufgrund Neuer Fossilfunde. Geologische Rundschau 54 (2): 715-732.

Naipauer, M.; Sato, A.; González, P.; Chemale, F.; Varela, R.; Llambías, E.J.; Greco, G.; Dantas, E. 2010. Eopaleozoic Patagonia-East Antarctica connection: Fossil and U-Pb evidence from El Jagüelito Formation. In South American Symposium on Isotope Geology, No. 7: 602-605.

Otamendi, J.E.; Patiño-Douce, A.E. 2001. Partial Melting of Aluminous Metagreywackes in the Northern Sierra de Comechingones, Central Argentina. Journal of Petrology 42 (9): 1751-1772.

Pankhurst, R.J.; Rapela, C.W.; Fanning, C.M.; Márquez, M. 2006. Gondwanide continental collision and the origin of Patagonia. Earth-Science Reviews 76 (3-4): 235-257.

Pankhurst, R.J.; Rapela, C.W.; López de Luchi, M.G.; Rapalini, A.E.; Fanning, C.M.; Galindo, C. 2014. The Gondwana connections of northern Patagonia. Journal of the Geological Society 171 (3): 313-328.

Passchier, C.W.; Trouw, R.A.J. 2005. Microtectonics (2 ${ }^{\text {nd }}$ Edition). Springer-Verlag: 366 p. Berlin.

Patiño Douce, A.E. 1996. Effects of pressure and $\mathrm{H}_{2} \mathrm{O}$ content on the compositions of primary crustal melts. Transactions of the Royal Society of EdinburghEarth Sciences 87: 11-21.

Patiño Douce, A.E.; Harris, N. 1998. Experimental Constraints on Himalayan Anatexis. Journal of Petrology 39 (4): 689-710.

Paton, C.; Hellstrom, J.; Paul, B.; Woodhead, J.; Hergt, J. 2011. Iolite: Freeware for the visualisation and processing of mass spectrometric data. Journal of Analytical Atomic Spectrometry 26: 2508-2518.

Petrus, J.A.; Kamber, B.S. 2012. VizualAge: A Novel Approach to Laser Ablation ICP-MS U-Pb Geochronology Data Reduction. Geostandards and Geoanalytical Research 36 (3): 247-270.

Puelles, P.; Abalos, B.; García de Madinabeitia, S.; Sánchez-Lorda, M.E.; Fernández-Armas, S.; Gil Ibarguchi, J.I. 2014. Provenance of quartz-rich metamorphic tectonite pebbles from the Black Flysch (W Pyrenees, N Spain): An EBSD and detrital zircon LA-ICP-MS study. Tectonophysics 632 (C): 123-137.

Pupin, J.P. 1980. Zircon and granite petrology. Contributions to Mineralogy and Petrology 73 (3): 207-220.

Ramos, V.A. 1975. Geología del sector oriental del Macizo Norpatagónico entre Aguada Capitán y la Mina Gonzalito, provincia de Río Negro. Revista de la Asociación Geológica Argentina 30 (3): 274-285.

Ramos, V.A.; Naipauer, M. 2014. Patagonia: Where does it come from? Journal of Iberian Geology 40 (2): 367-379.

Rapalini, A.E.; de Luchi, M.L.; Tohver, E.; Cawood, P. A. 2013. The South American ancestry of the North Patagonian Massif: Geochronological evidence for an autochthonous origin? Terra Nova 25 (4): 337-342.

Ravazzoli, I.; Sesana, F. 1977. Descripción geo- lógica de la Hoja 41c, Río Chico, provincia de Río Negro. Servicio Geológico Nacional, Boletín 148: 77 p. Buenos Aires.

Rubatto, D.; Williams, I.S.; Buick, I.S. 2001. Zircon and monazite response to prograde metamorphism in the Reynolds Range, central Australia. Contributions to Mineralogy and Petrology 140 (4): 458-468.

Sawyer, E.W. 1987. The role of partial melting and fractional crystallization determining discordant migmatites leucosome compositions. Journal of Petrology 28 (3): 445-473.

Sawyer, E.W. 2008. Atlas of Migmatites. (Cavers, P.B.; editor). The Canadian Mineralogist: 371 p. Ottawa.

Schaltegger, U.; Fanning, C.M.; Gunther, D.; Maurin, J.C.; Schulmann, K.; Gebauer, D. 1999. Growth, annealing and recrystallization of zircon and preservation of monazite in high-grade metamorphism: conventional and in-situ $\mathrm{U}-\mathrm{Pb}$ isotope, cathodoluminescence and microchemical evidence. Contributions to Mineralogy and Petrology 134 (2-3): 186-201.

Serra-Varela, S.; González, P.; Giacosa, R.; Heredia, N.; Pedreira, D.; Martín-González, F. 2015. Geología y relaciones estructurales entre los granitoides y metamorfitas del Complejo Colohuincul en San Martín de los Andes, Neuquén. In Simposio sobre Petrología Ignea y Metalogénesis Asociada, No. 3: 156-157. General Roca.

Serra-Varela, S.; Giacosa, R.; González, P.; Heredia, N.; Martín-González, F.; Pedreira, D. 2016. Geología y geocronología del basamento paleozoico de los Andes Norpatagónicos en el área de San Martín de los Andes. GeoTemas 16 (2): 431-434.

Serra-Varela, S.; González, P.D.; Giacosa, R.E.; Heredia, N.; Sato, A.M. 2017. Condiciones físicas del metamorfismo de alta temperatura y baja presión del basamento paleozoico inferior en el área de San Martín de los 
Andes, Neuquén. In Congreso Geológico Argentino, No. 20: 68-72. San Miguel de Tucumán.

Shand, S.J. 1943. The Eruptive Rocks, second edition. Wiley: 448 p. New York.

Siivola, J.; Schmid, R. 2007. List of Mineral abbreviations. IUGS Subcommission on the Systematics of Metamorphic Rocks: 1-14.

Sláma, J.; Kosler, J.; Condon, D.J.; Crowley, J.L.; Gerdes, A.; Hanchar, J.M.; Hanchar, J.M.; Horstwood, M.; Morris, G.; Nasdala, L.; Norberg, N.; Schaltegger, U.; Schoene, B.; Tubrett, M.; Whitehouse, M.J. 2008. Plesovice zircon-A new natural reference material for $\mathrm{U}-\mathrm{Pb}$ and $\mathrm{Hf}$ isotopic microanalysis. Chemical Geology 249 (1-2): 1-35.

Sun, S.; McDonough, W.F. 1989. Chemical and isotopic systematics of oceanic basalts: implications for mantle composition and processes. Geological Society, Special Publications 42 (1): 313-345. London.

Turner, J.C. 1965. Estratigrafía de Aluminé y adyacencias (provincia del Neuquén). Revista de la Asociacion Geologica Argentina 20 (2): 153-184.

Urraza, I.A.; Grecco, L.E.; Delpino, S.H.; Arrese, M. L.; Rapela, C.W. 2011. Petrología y Estructura del Complejo Ígneo-Metamórfico Aluminé, Provincia de Neuquén, Argentina. Andean Geology 38 (1): 98-118. doi: 10.5027/andgeoV38n1-a07.
Varela, R.; Basei, M.A.S.; Cingolani, C.A.; Passarelli, C.R. 2005. El basamento cristalino de los Andes norpatagónicos en Argentina: geocronología e interpretación tectónica. Revista Geológica de Chile 32 (2): 167-187. doi: 10.5027/andgeoV32 $\mathrm{n} 2-\mathrm{a} 01$.

Varela, R.; González, P.D.; Basei, M.A.S.; Sato, K.; Sato, A.M.; Naipauer, M.; García, V.; González, S.; Greco, G.A. 2011. Edad del Complejo Mina Gonzalito: revisión y nuevos datos. In Congreso Geológico Argentino, No. 18: 127-128. Neuquén.

Vavra, G.; Schmid, R.; Gebauer, D. 1999. Internal morphology, habit and $\mathrm{U}-\mathrm{Th}-\mathrm{Pb}$ microanalysis of amphibolite-to-granulite facies zircons: geochronology of the Ivrea Zone (Southern Alps). Contributions to Mineralogy and Petrology 134: 380-404.

White, R.W.; Pomroy, N.E.; Powell, R. 2005. An in situ metatexite-diatexite transition in upper amphibolite facies rocks from Broken Hill, Australia. Journal of Metamorphic Geology 23: 579-602.

Willner, A.P.; Glodny, J.; Gerya, T.V.; Godoy, E.; Massonne, H. 2004. A counterclockwise PTt path of high-pressure/low-temperature rocks from the Coastal Cordillera accretionary complex of southcentral Chile: constraints for the earliest stage of subduction mass flow. Lithos 75: 283-310. 